\title{
Carboxylate-functionalized mesoionic carbene precursors: decarboxylation, ruthenium bonding, and catalytic activity in hydrogen transfer reactions
}

\author{
Sara Sabater, ${ }^{\dagger, *, \#}$ Helge Müller-Bunz, ${ }^{\ddagger}$ and Martin Albrecht* ${ }^{\dagger, \hbar}$ \\ $\dagger$ Department of Chemistry and Biochemistry, Universität Bern, Freiestrasse 3, 3012 Bern, \\ Switzerland \\ $\$$ School of Chemistry and Chemical Biology, University College Dublin, Belfied, Dublin 4, \\ Ireland \\ \# Departamento de Quimica Inorganica y Organica, Universitat Jaume I, Avda. Sos Baynat s/n, \\ 12071 Castellon, Spain \\ E-mail: martin.albrecht@dcb.unibe.ch
}

\begin{abstract}
Metalation of a carboxylate-functionalized pyridyl-triazolium salt containing a N1-bound pyridyl substituent either directly with $\left[\mathrm{RuCl}_{2} \text { (cymene) }\right]_{2}$ or via a transmetalation procedure involving $\mathrm{Ag}_{2} \mathrm{O}$ and $\left[\mathrm{RuCl}_{2} \text { (cymene) }\right]_{2}$ induces rapid decarboxylation without concomitant metalation. Subsequent metalation of the formed $\mathrm{C} 4$ - and $\mathrm{C} 5$-unsubstituted triazolium salt is selective and occurs at the $\mathrm{C} 4$ position, i.e. remote from the pyridyl substituent, when the reaction is under kinetic control, and at the C5-position adjacent to the pyridyl group when performed under thermodynamic control. Preservance of the carboxylate functional group in the complex is achieved when the corresponding ester-functionalized pyridyl-triazolium salt is metalated first and then subjected to ester hydrolysis. The formed complex contains a $N, C$-bidentate chelating pyridyl-triazolylidene ligand with a pendant carboxylate unit that is not coordinating to the metal center. These new triazolylidene ruthenium complexes show modest catalytic activity in alcohol oxidation and better performance in the transfer hydrogenation of ketones. The data suggest that the presence of a pendant carboxylic acid or ester group is beneficial for enhancing the activity of the catalyst.
\end{abstract}




\section{Introduction}

The functionalization of key ligands has been widely and successfully explored as a concept for enhancing the catalytic activity of metal complexes. ${ }^{1}$ While early developments aimed at optimizing steric and electronic parameters of the ligand, ${ }^{2}$ recent efforts have been directed towards introducing functional groups that are non-innocent, and potentially assist the metal center, for example by reversible binding and releasing protons. ${ }^{3-5}$ The incorporation of appropriately functionalized ligands has been demonstrated to be relevant for the activation of small molecules in a catalytic cycle, where both metal and ligand simultaneously participate in bond making and breaking processes. ${ }^{6-9}$

Carbenes derived from 1,2,3-triazolium salts are an attractive ligand platform for such functionalization, as they combine unique donor properties with an extraordinary synthetic diversity. ${ }^{10-13}$ Moreover, these mesoionic (or abnormal) carbenes ${ }^{14-16}$ demonstrate some flexibility to adapt their donor strength and stabilize low as well as high metal oxidation states. ${ }^{17}$ The ligand precursors are conveniently accessible ${ }^{18}$ via [2+3] dipolar cycloaddition of alkynes and azides, ${ }^{19-21}$ a reaction that stands for its exceptionally broad functional group tolerance. ${ }^{22}$ This synthetic flexibility allows functional groups to be introduced to 1,2,3-triazolylidenes at positions that are not accessible with traditional imidazole-derived N-heterocyclic carbenes, since in triazolylidenes, one wingtip group (FG) is bound to a carbon. This linkage provides access to a greater variety of substituents such as heteroatoms and carbonyl groups, which are unstable functional groups in imidazole-derived carbenes. ${ }^{23-25}$ Depending on its nature, this functional group will induce metal chelation (A, Figure 1), ${ }^{26,27}$ or will provide a free Lewis basic site if chelation is prevented, ${ }^{28-30}$ for example by a pronounced yaw angle (B). ${ }^{31}$ Such a configuration of a non-coordinating Lewis base in close proximity to a Lewis acidic metal center ${ }^{32}$ may provide access to metal-ligand synergies, in particular for reversible bonding and release of substrate protons. ${ }^{33-35}$ It constitutes an organometallic analogue of Frustrated Lewis Pairs (FLPs), ${ }^{36,37}$ a concept that has been demonstrated to be extraordinarily powerful for bond activation processes. ${ }^{38-40}$ The combination of a Lewis acidic transition metal center with a non-coordinating Lewis-basic substituent thus combines intrinsic Lewis acid/base pair activity with the wellestablished catalytic properties of abnormal carbene metal complexes. ${ }^{41}$ Here we have addressed this concept by introducing carboxylate groups to a pyridyl-functionalized triazolylidene ligand. Methods to prevent decarboxylation have been established. The corresponding ruthenium complexes containing a carboxylate functionality in close proximity to the metal center display enhanced catalytic activity in transfer hydrogenation and dehydrogenative oxidation of alcohols when compared to the unfunctionalized analogue. 


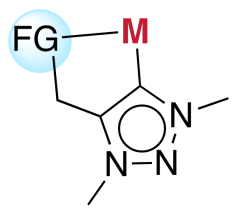

A

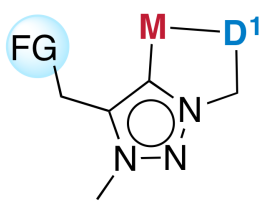

B

Figure 1 Functional group introduction in triazolylidenes induces either chelation (A) or provides an additional reactive group that can support the metal center $(\mathbf{B})$.

\section{Results and discussion}

Synthesis and characterization of triazolium salts. The synthesis of the carboxylatefunctionalized triazolium salt 3 started with a [3+2] cycloaddition of pyridine-2-azide and ethyl propiolate mediated by $\mathrm{CuI}$ and lutidine (Scheme 1), which afforded the previously described triazole $1{ }^{42}$ Hydrolysis of the triazole 1 with $\mathrm{LiOH} \cdot \mathrm{H}_{2} \mathrm{O}$ in a THF/MeOH$/ \mathrm{H}_{2} \mathrm{O}(1: 1: 1)$ mixture at $70{ }^{\circ} \mathrm{C}$ yielded the triazole $\mathbf{2}$ as a yellow solid in $89 \%$ yield. Subsequent $\mathrm{N}$-alkylation of $\mathbf{2}$ with methyl trifluoromethanesulfonate (MeOTf) in $\mathrm{CH}_{2} \mathrm{Cl}_{2}$ gave the triazolium salt $\mathbf{3}$ in almost quantitative yield (94\%). Despite the electron-withdrawing nature of the carboxylate group on the triazole heterocycle, alkylation was selectively occurring at the triazole N3 position. ${ }^{43,44}$ No products from pyridine N-alkylation were observed. ${ }^{45}$ Specifically, the carboxylic acid group gives rise to an absorption band in the IR spectrum at $1746 \mathrm{~cm}^{-1}$ and the acidic triazolium proton resonates at $\delta_{\mathrm{H}} 9.53$.

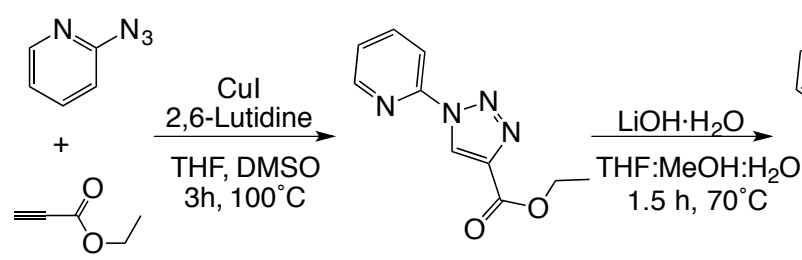

1

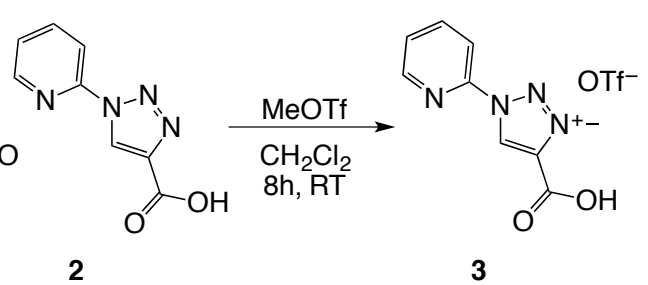

3

Scheme 1 Synthesis of triazolium salt 3.

Synthesis of Ru-triazolylidene complexes via decarboxylation. The triazolium salt $\mathbf{3}$ offers potentially two routes for metalation, including either decarboxylation, ${ }^{46,47}$ to afford a complex with a remote pyridine unit, or triazolium $\mathrm{C}-\mathrm{H}$ deprotonation and subsequent metalation, which 


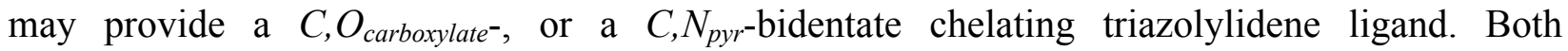
reactivities were probed by using different metalation conditions.

Thus, in an attempt to activate the $\mathrm{C}-\mathrm{H}$ bond, the triazolium salt $\mathbf{3}$ was reacted with $\mathrm{Ag}_{2} \mathrm{O}$ and $\left[\mathrm{RuCl}_{2}(p \text {-cymene })\right]_{2}$. This reaction gave a mixture of complexes $\mathbf{4}$ and $\mathbf{5}$ as orange air-stable solids ca. 30\% yield (Scheme 2). The product selectivity was strongly dependent on the reaction time, though not on in the quantity of ruthenium salt used for the transmetalation. Specifically, reaction of 3 with $\mathrm{Ag}_{2} \mathrm{O}$ in $\mathrm{MeCN}$ for extended periods of time (3 days) before adding the ruthenium salt to induce transmetalation afforded, after a further $16 \mathrm{~h}$, predominantly complex 4 . In contrast, short exposure of triazolium salt 3 to $\mathrm{Ag}_{2} \mathrm{O}$ ( $2 \mathrm{~h}$ or less) gave exclusively complex 5. Complex $\mathbf{6}$ formed spontaneously when dissolving complex $\mathbf{5}$ in chloroform, and produced a mixture of 5 and $\mathbf{6}$, as observed by ${ }^{1} \mathrm{H}$ NMR spectroscopy. The two complexes were readily separated by column chromatography.

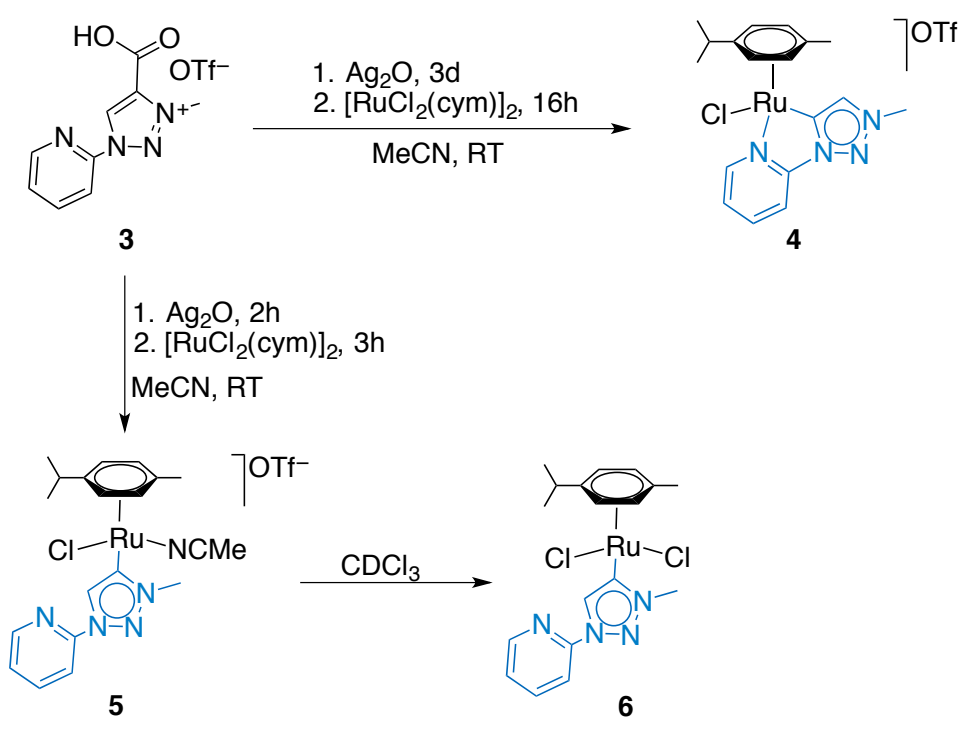

Scheme 2 Synthesis of complexes 4-6.

Complexes 4-6 were unambiguously characterized by NMR spectroscopy, mass spectrometry and elemental analysis. Nuclear Overhauser experiments and ${ }^{1} \mathrm{H}-{ }^{13} \mathrm{C}$ correlation spectroscopy provided evidence for the selectivity of metalation as well as for effective decarboxylation. Complex 4 features a resonance at $\delta_{\mathrm{H}} 8.42$ for the proton attached to the triazolylidene $\mathrm{C} 4$ nucleus, which constitutes a diagnostic indication for the decarboxylation of the triazolylidene ligand. The deshielded pyridyl $\alpha$ proton, appearing as a doublet of doublets centered at $\delta_{\mathrm{H}} 9.25$, strongly suggests $\mathrm{N}$-coordination of the pyridyl unit to the ruthenium center $\left(c f \delta_{\mathrm{H}} 8.69\right.$ in the ligand precursor 3). Furthermore, NOE experiments indicate a through-space interaction of the 
triazolylidene $\mathrm{CH}$ resonance and the singlet at $4.33 \mathrm{ppm}$ due to the $\mathrm{N}-\mathrm{CH}_{3}$ group, therefore further supporting metalation of the triazole-derived heterocyle at the $\mathrm{C} 5$ position.

The ${ }^{1} \mathrm{H}$ NMR spectrum of complex $\mathbf{5}$ reveals a similar resonance frequency for the triazolylidene C5-bound proton $\left(\delta_{\mathrm{H}} 8.43\right)$. While this resonance again indicates effective decarboxylation of the ligand precursor, the essentially identical chemical shift as observed for 4 makes this signal a poor probe for the selectivity of metalation. However, the pyridyl unit shows distinctly different features. In particular, the pyridyl $\alpha$ proton is shifted upfield from $\delta_{\mathrm{H}} 8.69$ in the triazolium salt 3 to $\delta_{\mathrm{H}} 8.63$ in complex 5 ( $c f$ downfield shift by $0.56 \mathrm{ppm}$ upon formation of 4 ). This shift suggests that the ruthenium center is not bound to the pyridine. Moreover, NOE experiments reveal a spatial interaction of the triazolylidene $\mathrm{CH}$ group with the pyridyl $\alpha$ proton, which is in full agreement with metalation of the triazolium at the $\mathrm{C} 4$ position. Coordination of $\mathrm{MeCN}$ was observed by a singlet at $\delta_{\mathrm{H}} 2.26$. Both complexes $\mathbf{4}$ and $\mathbf{5}$ are asymmetric at ruthenium and hence induce a splitting of the aromatic proton signals into four distinct resonances. The ${ }^{1} \mathrm{H}$ NMR spectroscopic data for the neutral complex $\mathbf{6}$ are very similar to those of $\mathbf{5}$, with the exception of the cymene proton resonances. Due to the presence of two chlorido ligands, the complex possesses a mirror plane and as a consequence, the aromatic proton resonances of the cymene ligand collapse into two doublets integrating for $2 \mathrm{H}$ each $\left(\delta_{\mathrm{H}} 5.42\right.$ and 5.28 , respectively).

Similar distinctions were observed in the ${ }^{13} \mathrm{C}$ NMR spectra of the complexes. Complex $\mathbf{4}$ featured resonances at $\delta_{\mathrm{C}} 171.5$ and 136.9 for the carbenic nucleus and the $\mathrm{C} 5-\mathrm{H}$ unit, while these resonances are substantially upfield shifted in complex $5\left(\delta_{\mathrm{C}} 161.4\right.$ and 130.7, for the carbenic carbon and $\mathrm{C} 4-\mathrm{H}$, respectively). The carbenic resonance in neutral complex 6 appears at lower field $\left(\delta_{\mathrm{C}} 167.8\right)$.

Crystals of $\mathbf{6}$ suitable for X-ray diffraction analysis were obtained by slow diffusion of pentane in a concentrated solution of the compound in chloroform. The molecular structure of $\mathbf{6}$ confirms the monodentate coordination at the $\mathrm{C} 4$ position of the triazolylidene ligand ( $\mathrm{C} 1$ in Figure 2). The structure can be regarded as a three-legged piano stool. Along with the triazolylidene ligand, two chlorides and a $p$-cymene ligand complete the coordination sphere about the ruthenium center. The Ru- $\mathrm{C}_{\text {carbene }}$ bond length is 2.052(5) $\AA$, in the range of other triazolylidene ruthenium complexes. ${ }^{48-55}$ The Ru-Cl and Ru- $\mathrm{C}_{\text {centroid }}$ bond lengths and the $\mathrm{C}_{\text {carbene }}-\mathrm{Ru}-\mathrm{Cl}$ angles are in the expected range. 


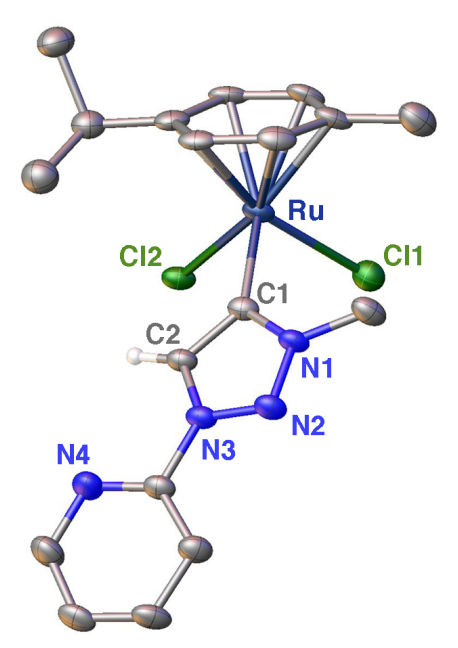

Figure 2 ORTEP diagram of complex 6. Ellipsoids are shown at 50\% probability level. All hydrogen atoms except $\mathrm{H}-\mathrm{C} 2$ are omitted for clarity. Selected bond lengths $(\AA)$ : $\mathrm{Ru}-\mathrm{C}(1)$ 2.052(5), $\mathrm{Ru}-\mathrm{Cl}(2)$ 2.4277(12), $\mathrm{Ru}-\mathrm{Cl}(1)$ 2.4313(14), $\mathrm{Ru}-\mathrm{C}_{\text {centroid }}$ 1.689; Selected bond angles $\left(^{\circ}\right): \mathrm{C}(1)-\mathrm{Ru}-\mathrm{Cl}(2)$ 84.29(15), C(1)-Ru-Cl(1) 87.14(15), $\mathrm{Cl}(2)-\mathrm{Ru}-\mathrm{Cl}(1)$ 87.25(5).

Formation of complex $\mathbf{4}$ upon extended stirring suggests that complex $\mathbf{4}$ or its silver precursor salt is the thermodynamically more favored product than the corresponding monodentate triazolylidene silver or ruthenium complex. Differentiation of the two products may occur at different stages and can principally involve a kinetic bias, i.e. distinct pathways for metalation, or a thermodynamic equilibration of product distribution, either when forming the triazolylidene silver intermediate or the ruthenium complex. Kinetic differentiation is conceivable when $\mathrm{Ag}_{2} \mathrm{O}$ selectively promotes deprotonation of the $\mathrm{C} 5-\mathrm{H}$ site in $\mathbf{3}$, leading to the $\mathrm{C} 5$-metalated chelate complex 4, whereas competitive decarboxylation may induce C4-metalation and formation of the monodentate triazolylidene complex 5. Complementary, thermodynamic control of product selectivity may be achieved when the $\mathrm{C}_{\mathrm{trz}}-\mathrm{H}$ site in complexes $\mathbf{4}$ and $\mathbf{5}$ are sufficiently acidic to react with residual $\mathrm{Ag}_{2} \mathrm{O}$, which leads to a transient heterobimetallic intermediate which can intramolecularly transmetalate. Such a pathway promotes a swap of the ruthenium and silver centers between $\mathrm{C} 4$ and $\mathrm{C} 5$ positions and thus will lead to a mixture of complexes that is controlled by the stability of the products. Alternatively, fast decarboxylation of $\mathbf{3}$ may produce a triazolium salt with both $\mathrm{C} 4$ and $\mathrm{C} 5$ positions protonated, and subsequent metalation will then be dictated by relative proton acidity and stability of the triazolylidene silver intermediate. To probe these different pathways, a series of experiments were carried out.

Attempts to directly interconvert the ruthenium complexes $\mathbf{5}$ or $\mathbf{6}$ to the supposedly more stable complex 4 did not meet any success. Prolonged heating of 5 or 6 in $\mathrm{MeCN}$ at elevated 
temperatures did not induce a shift of the metal center from the triazolium $\mathrm{C} 4$ position to $\mathrm{C} 5$ and instead only gradual loss of $p$-cymene and formation of the tetra(acetonitrile) species was observed. $^{51}$ A late stage transmetalation and equilibration was excluded based on experiments aimed at silver-mediated transformation of complex 5 into 4 . No reaction was observed when stirring complex 5 with $\mathrm{Ag}_{2} \mathrm{O}$, suggesting that proton abstraction at the $\mathrm{C} 5$ position of this triazolylide complex is not feasible. Different metalation pathways were investigated by reactions involving the triazolium salt 3 and $\left[\mathrm{RuCl}_{2}(p \text {-cymene) }]_{2}\right.$ in the absence of silver in refluxing $\mathrm{MeCN}$ or toluene. While this reaction did not produce any complex $\mathbf{5}$, essentially quantitative decarboxylation was observed, yielding the triazolium salt 7 with protons both at $\mathrm{C} 4$ and $\mathrm{C} 5$ position (Scheme 3). This triazolium salt 7 was previously described, and its formation was confirmed by the absence of the carbonyl IR stretch vibration at $1746 \mathrm{~cm}^{-1}$ and by the presence of two resonances in the ${ }^{1} \mathrm{H}$ NMR spectrum due to two triazolium protons with equal intensity $\left(\delta_{\mathrm{H}}\right.$ 9.14 and 8.72). ${ }^{56}$ Decarboxylation and formation of 7 was observed also when reacting compound 3 in the presence of a base such as $\mathrm{NaOAc}$ or $\mathrm{LiOH}$, or indeed $\mathrm{Ag}_{2} \mathrm{O}$ at room temperature. These experiments strongly suggest that the selectivity towards $\mathbf{4}$ or $\mathbf{5}$ is achieved during the silver carbene formation from triazolium salt 7 as the effective precursor for metalation. Such a conclusion is also supported by the fact that the product ratio between $\mathbf{4}$ and $\mathbf{5}$ is strongly influenced by the conditions applied for the formation of the triazolylidene silver intermediate (vide supra). In line with such a notion, the reaction of either the carboxylic acid precursor 3 or the pyridyl-triazolium salt 7 with $\operatorname{Ag}_{2} \mathrm{O}$ gave a complex signal pattern when monitoring the reaction by ${ }^{1} \mathrm{H}$ NMR spectroscopy, which has been attributed in parts to the formation of isomers due to C4- and C5-metalation as well as to coordination of the pyridyl unit to silver, which may lead to dimers and oligomers. Moreover, the fluxionality of silver coordination and the equilibrium between neutral $[\mathrm{AgX}($ carbene) $]$ species and cationic complexes $[\mathrm{Ag}(\mathrm{L})(\text { carbene })]^{+}(\mathrm{L}=$ pyridyl, triazolylidene $)$ is expected to further complicate the product mixture. ${ }^{57,58}$

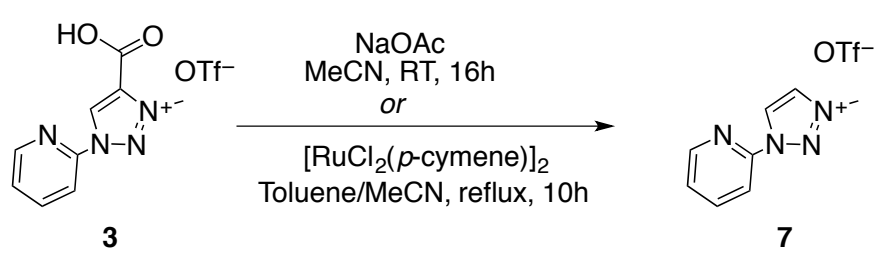

Scheme 3 Synthesis of 7 by decarboxylation of 3 .

The lability of the carboxylic moiety in $\mathbf{3}$ may open new opportunities for the metalation of triazolium salts via decarboxylative methods. ${ }^{46,47}$ However, all our attempts to use the 
carboxylate group as a carbene transfer agent to ruthenium(II) have been unsuccessful so far. Reaction of triazolium carboxylate 3 and $\left[\mathrm{RuCl}_{2}(p \text {-cymene) }]_{2}\right.$ at different temperatures and in variable stoichiometry induced release of $\mathrm{CO}_{2}$ and formation of 7 , but did not install the carbene at the ruthenium center. No complex 5 was detected in any of these experiments suggesting that decarboxylation is fast and likely induced by very weak nucleophiles.

Synthesis of carboxylate-functionalized triazolylidene ruthenium complexes. While the rapid decarboxylation prevented the synthesis of triazolylidene ruthenium complexes with a pendant carboxylate group, such complexes were accessible via a modified procedure. Alkylation of the ester-functionalized triazole $\mathbf{1}$ ( $c f$. Scheme 1) and metalation of the corresponding triazolium salt 8 avoided decarboxylation. Treatment of triazolium salt 8 with $\mathrm{Ag}_{2} \mathrm{O}$ in $\mathrm{CH}_{2} \mathrm{Cl}_{2}$ and transmetalation of the triazolylidene silver intermediate with $\left[\mathrm{RuCl}_{2}(p \text {-cymene) }]_{2}\right.$ at room temperature for $16 \mathrm{~h}$ afforded complex 9 with a $C, N$-bidentate chelating pyridyl-triazolylidene ligand in 77\% yield (Scheme 4). Complex 9 was purified by normal column chromatography $\left(\mathrm{SiO}_{2}\right)$ and is an orange solid that is completely stable towards air and moisture. Chelation was supported by the high-field resonance of the pyridyl $\alpha$ proton (doublet at $\delta_{\mathrm{H}}$ 9.27) and the four distinct resonances of the aromatic cymene protons in the 6.3-5.4 ppm range, indicative of an asymmetric environment around the ruthenium center. The carbenic carbon nucleus was observed at a typical field $\left(\delta_{\mathrm{C}} 177.1\right)$. Direct evidence for the preservation of the ester group was obtained by the characteristic signals in the ${ }^{1} \mathrm{H}$ and ${ }^{13} \mathrm{C}$ NMR spectra (e.g. $\delta_{\mathrm{C}=\mathrm{O}} 159.2$ ), by the characteristic stretch vibration at $1729 \mathrm{~cm}^{-1}$ in the IR spectrum, and by the expected [M-OTf] fragment at 502.3 amu in mass spectrometry.

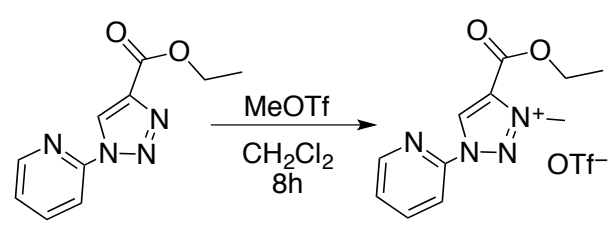

1

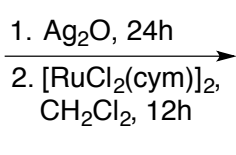

8

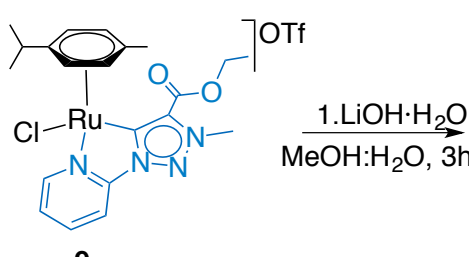

9

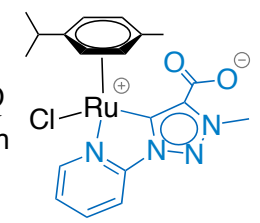

10

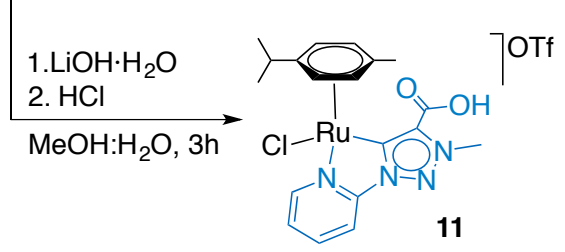

Scheme 4 Synthesis of complexes 9-11

Unequivocal evidence for the molecular structure of 9 was obtained by X-ray diffraction studies. Crystals of 9 suitable for X-ray diffraction analysis were grown by slow diffusion of pentane into a solution of the compound in $\mathrm{CH}_{2} \mathrm{Cl}_{2}$. The structure of 9 shows the typical three-legged piano 
stool conformation (Figure 3), with a $p$-cymene as 'seat', and a chloride and a chelating pyridyltriazolylidene forming the 'legs' bound to the $\mathrm{Ru}(\mathrm{II})$ center. The $\mathrm{Ru}-\mathrm{C}_{\text {carbene }}$ bond length is 2.049(2) Á, and is thus in the expected range, when compared to similar complexes reported for the same metal fragment containing triazolylidene ligands. ${ }^{48-51}$ The molecular structure confirms the chelation of the pyridyl group, which produces a five-membered metalacycle with an acute bite angle $\mathrm{C}(1)-\mathrm{Ru}-\mathrm{N}(4)$ of $77.92(8)^{\circ}$.

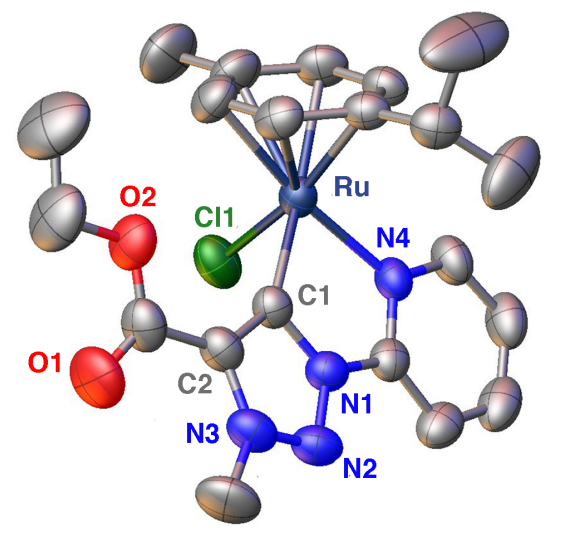

Figure 3 ORTEP diagram of complex 9 (50\% probability ellipsoids, OTf $^{-}$anion and hydrogen atoms omitted for clarity). Selected bond lengths (Á): $\mathrm{Ru}-\mathrm{C}(1)$ 2.049(2), Ru-N(4) 2.0983(18), $\mathrm{Ru}-\mathrm{Cl}$ 2.4004(6), $\mathrm{Ru}-\mathrm{C}_{\text {centroid }}$ 1.706; Selected bond angles ( $\left.{ }^{\circ}\right)$ : $\mathrm{C}(1)-\mathrm{Ru}-\mathrm{Cl}$ 84.96(6), $\mathrm{C}(1)-\mathrm{Ru}-$ $\mathrm{N}(4) 77.92(8), \mathrm{N}(4)-\mathrm{Ru}-\mathrm{Cl} 82.34(5)$.

Subsequent basic hydrolysis of the ester functionality in complex 9 was accomplished by reaction of 9 with two equivalents of $\mathrm{LiOH}$ in a $\mathrm{MeOH} / \mathrm{H}_{2} \mathrm{O}$ (1:1) mixture, which gave the zwitterionic carboxylate-substituted triazolylidene complex $\mathbf{1 0}$ as a yellow solid in $83 \%$ yield (Scheme 4). Acidic work up using an aqueous $\mathrm{HCl}$ solution (1M) afforded complex 11 containing a pendant carboxylic acid functionality. While complexes $\mathbf{9}$ and $\mathbf{1 1}$ are air- and moisture stable solids, complex $\mathbf{1 0}$ is highly hygroscopic. It is worth noting that the neither the acidic nor the basic conditions affected the $\mathrm{Ru}-\mathrm{C}_{\mathrm{trz}}$ bond, and both complexes were obtained in high yields $(83 \%$ for 10, $92 \%$ for 11). Moreover, it is remarkable that the triazolium carboxylate is sensitive towards $\mathrm{LiOH}$ and undergoes rapid decarboxylation (see above), whereas the ruthenium triazolylidene is robust under ambient conditions (RT, several days). Obviously, the $\mathrm{C}_{\mathrm{trz}}-\mathrm{C}_{\mathrm{COO}}$ bond is substantially more stable when the triazole heterocycle is more electron rich and bound to a metal center. In the triazolium salt, which features a covalent $\mathrm{C}_{\mathrm{trz}}-\mathrm{H}$ bond rather than a partially ionic $\mathrm{C}_{\mathrm{trz}}-\mathrm{Ru}$ bond, release of $\mathrm{CO}_{2}$ is considerably more favored. 
Successful ester hydrolysis was indicated spectroscopically by the absence of the signals corresponding to the ethyl group in the ${ }^{1} \mathrm{H}$ and ${ }^{13} \mathrm{C}$ NMR spectra. For complex 11, a broad resonance at $4.3 \mathrm{ppm}$ was attributed to the acidic $\mathrm{COOH}$ proton. In the ${ }^{13} \mathrm{C}$ NMR spectrum, diagnostic shifts for the ruthenium-bound triazolylidene and the carbonyl carbon were noted. For 10 and 11, the carbenic carbon was observed at higher field than in the ester analogue $\left(\delta_{C} 172.3\right.$ and $174.9 \mathrm{ppm}$, respectively, vs 177.1 in 9). The carbonyl unit appeared at $\delta_{\mathrm{C}=\mathrm{O}} 156.7$ in the carboxylate complex 10 and at $\delta_{\mathrm{C}=\mathrm{O}} 161.4$ in the carboxylic acid homologue. Mass spectrometry further supported ester hydrolysis and showed a signal at $475.7 \mathrm{amu}$ for the carboxylic acid cation $[\mathrm{M}-\mathrm{OTf}]^{+}$, indicating the loss of the ethyl fragment when compared to complex $\mathbf{9}$. The carboxylate analogue $\mathbf{1 0}$ is formally neutral and ionization therefore involves the loss of the metal-bound chloride, resulting in a lower mass of the cationic fragment (439.0 amu for [M$\left.\mathrm{Cl}]^{+}\right)$. Moreover, the characteristic IR stretching vibrations at 1618 and $1735 \mathrm{~cm}^{-1}$ for $\mathbf{1 0}$ and $\mathbf{1 1}$, respectively, are characteristic for the presence of a carboxylate and a carboxylic acid group. ${ }^{59}$

\section{Modification of ancillary ligands.}

Substitution of the $p$-cymene ligand in $\mathbf{9}$ was achieved by thermal replacement according to established procedures. ${ }^{51,60-63}$ Accordingly, reaction of complex 9 with AgOTf in refluxing $\mathrm{MeCN}$ for $24 \mathrm{~h}$ afforded the solvento complex 12 as a yellow solid in $75 \%$ yield (Scheme 5). The reaction of 12 with 2.5 equivalents of $\mathrm{PPh}_{3}$, in ortho-dichlorobenzene at $110^{\circ} \mathrm{C}$ for 3 days gave complex 13, which was obtained by precipitation with $\mathrm{Et}_{2} \mathrm{O}$ as a yellow air-stable solid in $95 \%$ yield. In contrast the solvento complex $\mathbf{1 2}$ is sensitive to air and gradually degrades as indicated by a color change from yellow to green over several days.

The successful replacement of the $p$-cymene ligand in $\mathbf{1 2}$ was deduced from ${ }^{1} \mathrm{H}$ NMR spectroscopy analysis by the loss of the resonances due to the $p$-cymene ligand and the appearance of characteristic signals attributed to coordinated $\mathrm{MeCN}$. Only two sets of resonances were observed in 1:2 ratio $\left(\delta_{\mathrm{H}} 2.50\right.$ and 2.08 , respectively); this pattern suggests octahedral coordination geometry about the ruthenium center, with two symmetry-related $\mathrm{MeCN}$ ligands in mutual trans position, and one $\mathrm{MeCN}$ each trans to the triazolylidene and the pyridyl ligand. While a theoretical 1:1:2 ratio of $\mathrm{MeCN}$ signals would therefore be expected, previous work revealed a fast exchange of the $\mathrm{MeCN}$ ligand trans to the carbene with the NMR solvent $\left(\mathrm{CD}_{3} \mathrm{CN}\right.$; see Experimental section for further details). ${ }^{51}$

Coordination of two $\mathrm{PPh}_{3}$ ligands in complex 13 is evidenced by the multiplet in the aromatic region integrating for 30 protons, and the disappearance of the signal attributed to two coordinated MeCN ligands $\left(\delta_{\mathrm{H}} 2.08\right.$ in 12). The spectrum shows only one set of ligand signals, 
suggesting the formation of only one of the possible four diastereomers. The ${ }^{31} \mathrm{P}$ NMR spectrum of 13 reveals a single resonance at $\delta_{\mathrm{P}} 29.5$, indicative for the presence of symmetry-related phosphines and hence a mutual trans orientation as depicted in Scheme 5. This trans configuration and the observation of only one $\mathrm{MeCN}$ ligand further support that the solvent ligand trans to the triazolylidene is exchanging rapidly on the NMR time scale. In agreement with this structure, the metalated carbene carbon appears in the ${ }^{13} \mathrm{C}$ NMR spectrum as a triplet at $\delta_{\mathrm{C}}$ 183.4. The multiplicity and coupling constant $\left({ }^{2} J_{\mathrm{CP}}=11.5 \mathrm{~Hz}\right)$ supports the coordination of two symmetry-related $\mathrm{PPh}_{3}$ ligands in mutual trans disposition. ${ }^{64}$

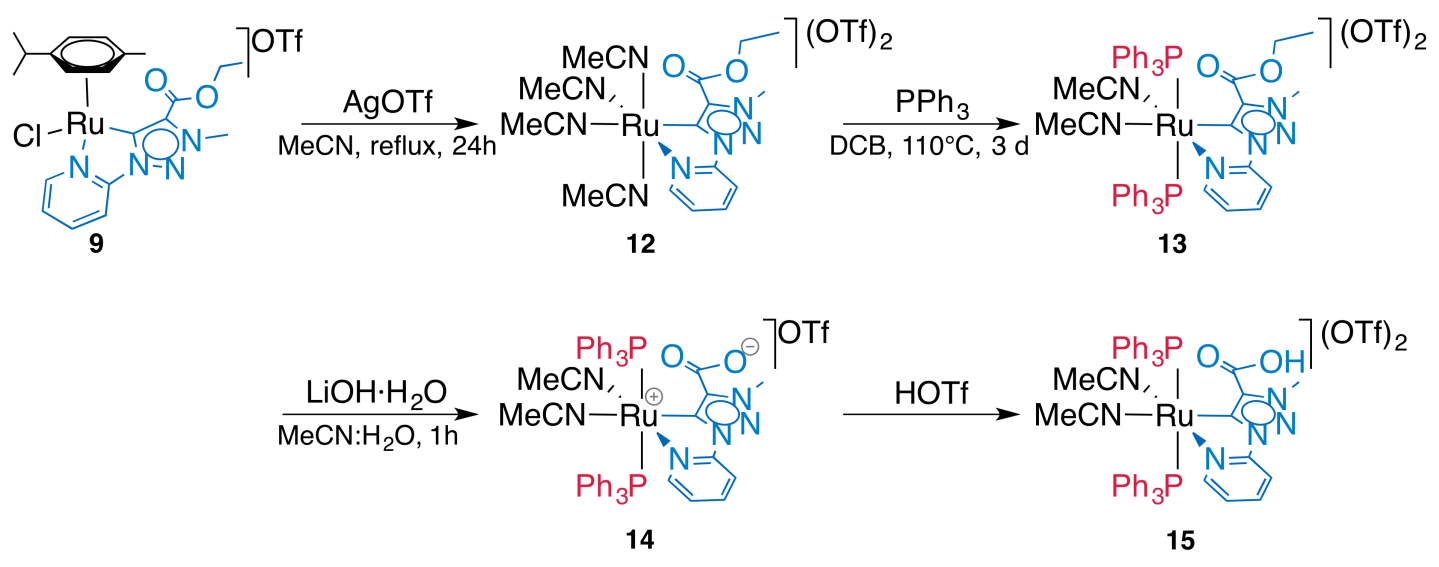

Scheme 5 Synthesis of complexes 12-15

Similar to the reactivity of $\mathbf{9}$, basic hydrolysis of the ester functionality in $\mathbf{1 3}$ afforded the zwitterionic carboxylate triazolylidene complex 14 (64\% yield) and the carboxylic acidfunctionalized triazolylidene complex 15 (in 52\% yield, Scheme 5). The hydrolysis protocol was similar to the one described for the preparation of $\mathbf{1 0}$ and $\mathbf{1 1}$, only a mixture of $\mathrm{MeCN} / \mathrm{H}_{2} \mathrm{O}$ was used as solvent in order to avoid solvent exchange processes. Complexes 14 and 15 are yellow solids that are fully air- and moisture- stable in solution and in the solid state. Hydrolysis and formation of complexes 14 and $\mathbf{1 5}$ was supported by the characteristic NMR and mass spectrometric data, which feature similar changes as those described for $\mathbf{1 0}$ and $\mathbf{1 1}$ (see above and Experimental Section).

Catalytic transfer hydrogenation. The availability of a pendant pyridyl group in complexes 4-6 and of a carboxylate functionality in complexes 9-15 provides opportunities to explore synergistic ligand-metal interactions. In particular, hydrogen transfer reactions such as transfer hydrogenations and dehydrogenative oxidations are known to benefit from the presence of ligand-centered basic sites by cooperative hydride/proton transfer to the metal and ligand, 
respectively ${ }^{65-72}$ Hence, the new ruthenium complexes were investigated as catalyst precursors for the ketone reduction via transfer hydrogenation. The reactions were carried out using acetophenone as benchmark substrate under standard conditions, ${ }^{73-77}$ i.e. refluxing $i$-PrOH as a formal dihydrogen donor, $\mathrm{KOH}(10 \mathrm{~mol} \%)$ as activator, and a complex loading of $1 \mathrm{~mol} \%{ }^{78,79} \mathrm{~A}$ first screening revealed several trends (Table 1). Complex 4 with a $C, N$-bidentate chelating triazolylidene produces a less active catalyst than the monodentate C4-bound triazoldylidene ruthenium complexes 5 and $\mathbf{6}$ (entries 1-3). Especially the cationic complex 5 performed well and reached $88 \%$ conversion within $1 \mathrm{~h}$. This activity is comparable to related triazolylidene ruthenium complexes. ${ }^{50,80}$ Chelation presumably prevents fast conversions and hence reduces the yield in comparison to the non-chelated complexes. This drawback is effectively overcome when installing a carboxyl group onto the triazolylidene C4-position, and in particular complexes 9 and 11 with a pendent ester or carboxylic acid group give essentially quantitative yields after $1 \mathrm{~h}$ (entries 4 and 6). While this activity is higher than when using monodentate triazolylidene ruthenium catalyst precursors, it is still two orders of magnitude lower than some of the best performing transfer hydrogenation systems. ${ }^{81-87}$ The carboxylate derivative $\mathbf{1 0}$ is less effective and reached only $75 \%$ conversion after the same reaction time (entry 5), likely because this complex undergoes faster decarboxylation than complexes 9 and $\mathbf{1 1}$ (vide infra). The similar catalytic activity of complexes $\mathbf{9}$ and $\mathbf{1 1}$ may tentatively be explained by an in situ ester hydrolysis under the basic and protic conditions used for the catalytic experiments. These conditions are identical to those applied for the hydrolysis of complex 9 when preparing complex 11 ( $c f$. Scheme 4). Such a model is further supported by a time-conversion analysis of the catalytic reaction. Time-resolved monitoring of the conversion showed a faster onset of catalytic activity when using complex 11 vs 9 (Figure S1) ${ }^{88}$ The delayed activation of 9 suggests relatively slow initial activation of the catalyst derived from complex $\mathbf{9}$ and hence reflects the differences of ester $v s$. carboxylic acid functionalization.

Table 1. Catalytic transfer hydrogenation of acetophenone ${ }^{a}$

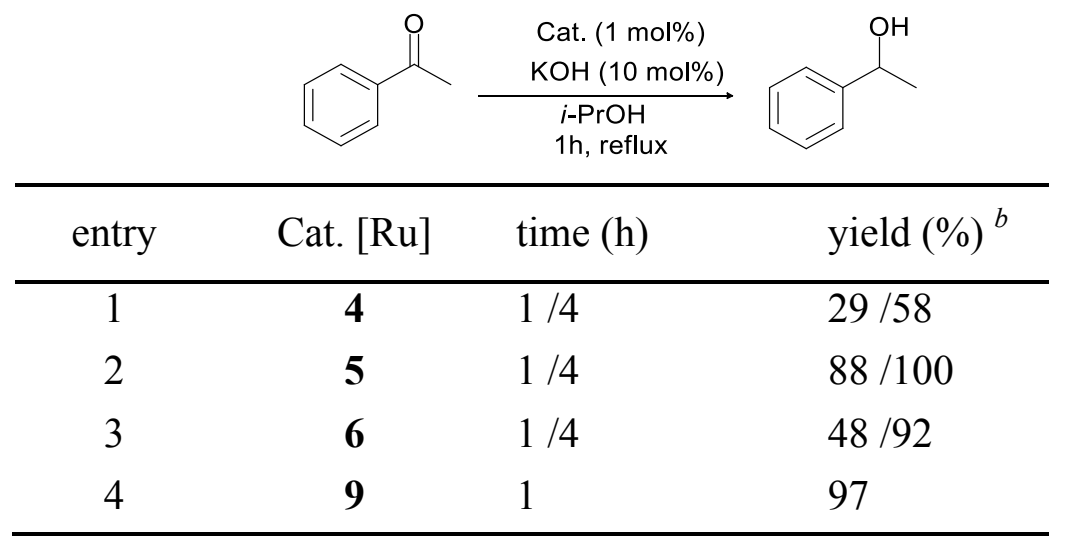




\begin{tabular}{llll}
\hline 5 & $\mathbf{1 0}$ & 1 & $75(9)$ \\
6 & $\mathbf{1 1}$ & 1 & $95(0)$ \\
7 & $\mathbf{1 4}$ & 1 & 16 \\
\hline
\end{tabular}

a) General reaction conditions: acetophenone $(0.6 \mathrm{mmol}), \mathrm{KOH}(0.06 \mathrm{mmol}),[\mathrm{Ru}](0.006 \mathrm{mmol}, 1$ mol\%), 2-propanol ( $2 \mathrm{~mL})$, reflux temperature; b) determined by ${ }^{1} \mathrm{H}$ NMR spectroscopy with anisole as internal standard (yields in parenthesis from base-free reaction).

The transfer hydrogenation under base-free conditions using complexes 10 or 11 was ineffective (entries 5 and 6, yield in parenthesis), indicating that the pendant carboxylic group is not sufficiently basic for the formation of the reactive isopropoxide. The octahedral carboxylate derivative 14 containing two weakly coordinating $\mathrm{MeCN}$ ligands displayed remarkably little activity and reached a modest $16 \%$ yield after $1 \mathrm{~h}$ under conditions where the cymene analogue with the same ligand scaffold achieved $75 \%$ conversion ( $c f$ entries 5,7).

Based on this initial catalyst screening, complexes 4, 9, and $\mathbf{1 1}$ were used as catalyst precursors for a small set of different substrates (Table 2). Both benzophenone and substituted acetophenone derivatives were transfer hydrogenated almost quantitatively within $1 \mathrm{~h}$ when using complexes 9 and $\mathbf{1 1}$ with carbonyl functionalities at the triazolylidene. Cyclohexanone was less reactive and was obtained in 53\% spectroscopic yield after $1 \mathrm{~h}$ when using complex 9. As noted in Table 1, complex 4 is significantly less active, indicating that the presence of a COOR substituent at the triazolylidene ligand improves catalytic performance. It is worth noting that the activity of complex $\mathbf{9}$ and $\mathbf{1 1}$ are essentially identical with the used substrates, which points to a high similarity of the catalytically active species. Ester hydrolysis of $\mathbf{9}$ in situ under the basic conditions used for catalysis is plausible, which suggests a beneficial role of the carboxylate functionality in the transfer hydrogenation reaction. ${ }^{89}$

Table 2. Catalytic transfer hydrogenation of different ketones ${ }^{a}$

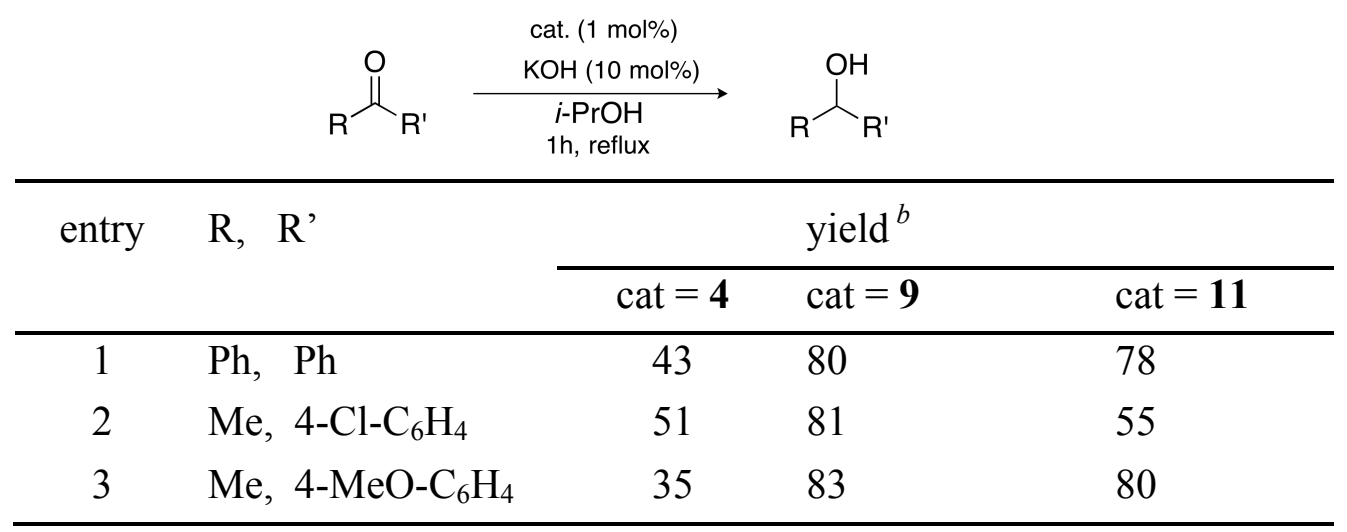


a) General reaction conditions: substrate $(0.6 \mathrm{mmol}), \mathrm{KOH}(0.06 \mathrm{mmol}),[\mathrm{Ru}](0.006 \mathrm{mmol}, 1$ mol\%), 2-propanol (2 mL), reflux temperature; conversions selectively to the corresponding alcohol, determined by ${ }^{1} \mathrm{H}$ NMR spectroscopy with anisole as internal standard, average of 2 runs, with differences less than $5 \%$ between runs.

Mechanistic insights were obtained from running a transfer hydrogenation experiment in hepta deuterated isopropanol, $\left(\mathrm{CD}_{3}\right)_{2} \mathrm{CD}-\mathrm{OH}$ as selective $\mathrm{HD}$ donor using benzophenone as acceptor. The diphenylmethanol obtained from this reaction was essentially completely deuterated at the carbinol position with less than $5 \%$ hydrogen incorporation according to ${ }^{1} \mathrm{H}$ NMR spectroscopy. The selective transfer of a deuterium from the carbon site of the hydrogen donor to the carbonyl carbon of the substrate is commensurate with a monohydride mechanism for the transfer hydrogenation. ${ }^{77,90}$ Attempts to detect such a ruthenium hydride species by ${ }^{1} \mathrm{H}$ NMR spectroscopy from the reaction of complex 9 and $i-\mathrm{PrOH}$ in the presence of stoichiometric quantities of $\mathrm{KO} t \mathrm{Bu}$ have failed thus far. However, further support for a molecularly defined homogeneously operating catalyst was obtained from poisoning experiments using $\mathrm{PPh}_{3} .{ }^{91}$ When an excess (100 equiv per complex 9) of $\mathrm{PPh}_{3}$ was added to a catalytic run after $10 \mathrm{~min}(4 \%$ conversion, see also Fig. S1), the activity ceased and after $1 \mathrm{~h}$, the conversion was unchanged (4\%, cf $97 \%$ in the absence of $\left.\mathrm{PPh}_{3}\right)$. Such behavior may be rationalized with competitive coordination of phosphine to ruthenium, which prevents substrate binding to the metal center.

Base-free dehydrogenation of benzyl alcohol. Based on precedents with similar complexes, ${ }^{48-}$ 50,92 the new triazolylidene ruthenium complexes were evaluated as catalyst precursors for the oxidant- and base-free oxidation of benzyl alcohol. The catalytic experiments were performed in $o$-dichlorobenzene with a catalyst loading of $5 \mathrm{~mol} \%$, at $150^{\circ} \mathrm{C}$ in an open system. The results shown in Table 3 indicate that all ruthenium complexes were active in the dehydrogenative oxidation of benzyl alcohol. When comparing the catalytic outcomes induced by complexes 4-6, distinct differences in performance were observed (entries 1-3). The catalytic activity of the pyridine-chelated complex $\mathbf{4}$ was higher than that of the monodentate complexes $\mathbf{5}$ and $\mathbf{6}$. Recent studies revealed that chelation of a pyridine consistently reduced the catalytic activity when compared to monodentate triazolylidenes, ${ }^{21}$ therefore the differences noted for complexes 4-6 presumably originate from the presence of the pendant pyridine unit. Mechanistic studies have suggested that solvolysis of the complex and coordination of the alcohol substrate are likely rate limiting. ${ }^{49}$ Hence, the presence of a free pyridine unit may favorably compete with the substrate for coordination to ruthenium and hence inhibit conversion. Such a rate-limiting step also agrees with a higher activity of the solvento complex $\mathbf{5}$ compared to the neutral chloride complex $\mathbf{6}$. The ester-functionalized complex 9 displayed the highest activity and accomplished essentially full 
conversion to benzaldehyde within $16 \mathrm{~h}$ (entry 4), similar to the most active monodentate carbene ruthenium complexes reported thus far. ${ }^{48,49}$ The carboxylic acid derivative $\mathbf{1 1}$ was less effective than the carboxylates 10 and $\mathbf{1 4}$ (entries 5-7). Interestingly, complex $\mathbf{1 1}$ showed also lower catalytic performance than the analogous complex 4 without carboxylate group at $\mathrm{C} 4$ ( $c f$ entries $1,7)$. The different catalytic activity is probably due to the difference in solubility and stability of the complexes in $o$-dichlorobenzene at $150{ }^{\circ} \mathrm{C}$, and not necessarily induced by functional groups at the ligand. Stability issues may arise in particular from thermal decarboxylation, and this process may gradually transform complexes $\mathbf{1 0}$ and $\mathbf{1 1}$ to the same catalytically active species as that derived from complex 4 .

Table 3. Oxidation of benzyl alcohol with triazolylidene $\mathrm{Ru}(\mathrm{II})$ complexes $^{a}$

\begin{tabular}{ccc}
\hline cat. & $\begin{array}{c}\text { Cat. }(5 \mathrm{~mol} \%) \\
16 \mathrm{DCB}, 150^{\circ} \mathrm{C}\end{array}$ \\
entry & cat. & yield (\%) \\
1 & $\mathbf{4}$ & 83 \\
2 & $\mathbf{5}$ & 55 \\
3 & $\mathbf{6}$ & 50 \\
4 & $\mathbf{9}$ & 95 \\
5 & $\mathbf{1 0}$ & 73 \\
6 & $\mathbf{1 1}$ & 54 \\
7 & $\mathbf{1 4}$ & 86 \\
\hline
\end{tabular}

a) General reaction conditions: benzyl alcohol $(0.2 \mathrm{mmol}),[\mathrm{Ru}](0.01 \mathrm{mmol}, 5 \mathrm{~mol} \%)$, $o$-dichlorobenzene $(2 \mathrm{~mL})$, $150{ }^{\circ} \mathrm{C}$; Yields determined by ${ }^{1} \mathrm{H}$ NMR integration (anisole as a standard).

Thermal stability of the carboxylate complexes. The stability of complex 11 towards decarboxylation was probed in order to gain a better understanding of the differences in catalytic activity. Complex 11 undergoes decarboxylation under basic conditions, i.e. in the presence of 2 equivalents of $\mathrm{KOH}$. Stirring such a basic $\mathrm{MeCN}$ solution at $80^{\circ} \mathrm{C}$ induced the formation of complex 4 in 30\% NMR yield within $30 \mathrm{~min}$. After $5 \mathrm{~h}$ the complex partially lost the $p$-cymene ligand and decarboxylation was almost complete ( $90 \%$ of 4$)$. The same result was obtained under base-free conditions. Stirring complex 11 in pure $\mathrm{MeCN}$ at $80^{\circ}$ for $8 \mathrm{~h}$ induced $95 \%$ decarboxylation and formation of 4 (Scheme 6). 
This reactivity of $\mathbf{1 1}$ towards decarboxylation explains the differences in activity of the complexes in the catalytic transformations, as the decarboxylation of $\mathbf{1 1}$ occurs within $5 \mathrm{~h}$. The transfer hydrogenation reactions were complete within $1 \mathrm{~h}$, and hence the carboxylate moiety is presumed to remain largely intact and thus can play an active role as demonstrated by the different catalytic performance. The oxidative dehydrogenation of benzyl alcohol requires much longer reaction times, and therefore the differences in the catalytic activity of the complexes are not attributed to the presence/absence of the carboxylate group at the triazole ligand but on degradation and solubility factors.

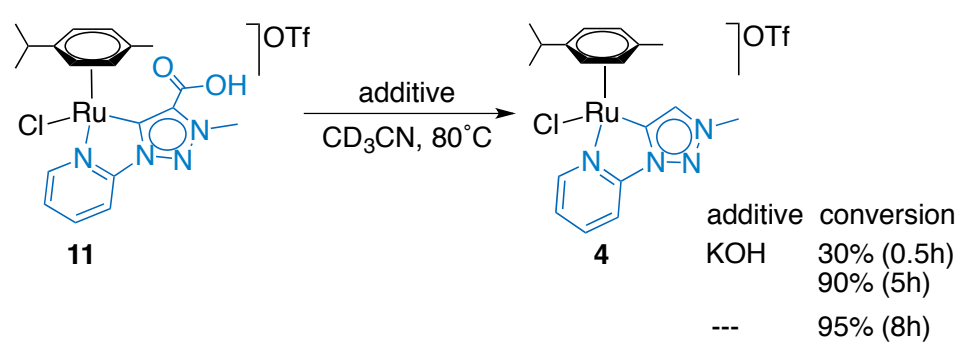

Scheme 6 Thermal and base-induced decarboxylation of complex 11.

\section{Conclusions}

A straightforward synthetic route has been disclosed to prepare mesoionic triazolylidene precursors containing a carboxylate functionality directly attached to the heterocycle. Such functionalization is not possible in imidazole-derived carbenes due to the inherent lability of the azolium carboxylate unit. While facile decarboxylation of the new ligand precursors provides opportunities for the metalation of triazolium salts via $\mathrm{CO}_{2}$ release, all our attempts of using the carboxylate functionality as carbene transfer agent have been unsuccessful thus far, possibly because of unfavorable kinetics of decarboxylation vs metalation This reactivity pattern evidences different properties of triazolylidenes compared to 2-imidazolylidenes. More successful carbene transfer may be achieved by utilizing different metal precursors. The formation of carboxylate-functionalized triazolylidene ruthenium complexes was accomplished by an alternative route involving first metalation followed by ester hydrolysis at the complex. Such post-modification of the ligand emphasizes the stability of the triazolylidene-ruthenium bond. Catalytic applications indicate that the carboxylate group enhances the catalytic activity of the complex in transfer hydrogenation though not in alcohol dehydrogenation reactions. The effect is substantial in transfer hydrogenation as rates are essentially doubled. These results 
suggest that the carboxylate group is actively participating in bond activation processes and/or in reversible proton bonding and release. Introducing functional groups directly to the $\mathrm{N}$ heterocyclic carbenic ligand is thus a useful concept to modulate and improve (catalytic) properties of the metal center, and is much more facile with triazolylidenes than with other Nheterocyclic carbenes.

\section{Experimental section}

General Procedures. All manipulations were carried out under a nitrogen atmosphere using standard Schlenk techniques and high vacuum, unless otherwise stated. Anhydrous solvents were dried using a solvent purification system (SPS M BRAUN) or purchased from Aldrich and degassed prior to use by purging with dry nitrogen and kept over molecular sieves. All other reagents were used as received from commercial suppliers. Ethyl-1-(2-pyridyl)-1H-1,2,3-triazole-

4-carboxylate 1 was prepared according to a literature procedure. ${ }^{42}$ All NMR spectra were recorded on Varian Innova spectrometers using $\mathrm{CD}_{3} \mathrm{CN}$ as solvent at room temperature unless otherwise stated. Chemical shifts ( $\delta$ in ppm, coupling constants $J$ in $\mathrm{Hz}$ ) were referenced to residual solvent resonances. Elemental analyses were carried out by the microanalytical services of University College Dublin. Electrospray mass spectra (ESI-MS) were recorded on a MicromassQuatro LC instrument, and nitrogen was employed as drying and nebulizing gas.

Synthesis of pyr-triazole-COOH 2 and pyr-trzH(OTf)-COOH 3. In a round-bottom flask were mixed ethyl-1-(2-pyridyl)-1H-1,2,3-triazole-4-carboxylate 1 (500 mg, $2.29 \mathrm{mmol}$ ) and $\mathrm{LiOH} \cdot \mathrm{H}_{2} \mathrm{O}(289 \mathrm{mg}, 6.88 \mathrm{mmol})$ in a $\mathrm{THF} / \mathrm{MeOH} / \mathrm{H}_{2} \mathrm{O}$ mixture $(15 \mathrm{~mL}, 1: 1: 1$ volume ratio) and the solution was stirred for $1.5 \mathrm{~h}$ at $70{ }^{\circ} \mathrm{C}$. The mixture was concentrated under reduced pressure and extracted with EtOAc $(3 \times 20 \mathrm{~mL})$. The combined aqueous layers were acidified with an $\mathrm{HCl}$ solution (4 M). The product precipitated and the mixture was extracted with EtOAc. The organic layers were combined and the solvent was removed under reduced pressure to afford 1-(2pyridyl)-1H-1,2,3-triazole-4-carboxylic acid 2 as a spectroscopically pure light brown solid (387 mg, 89\%). ${ }^{1} \mathrm{H}$ NMR (300 MHz, $\mathrm{CDCl}_{3}$ ): $\delta 9.22$ (s, 1H, NCHC), 8.61-8.53 (m, 1H, $\mathrm{CH}_{\mathrm{py}}$ ), 8.34$8.24\left(\mathrm{~m}, 1 \mathrm{H}, \mathrm{CH}_{\mathrm{py}}\right), 8.05-7.95\left(\mathrm{~m}, 1 \mathrm{H}, \mathrm{CH}_{\mathrm{py}}\right), 7.51-7.41\left(\mathrm{~m}, 1 \mathrm{H}, \mathrm{CH}_{\mathrm{py}}\right)$.

A suspension of $2(300 \mathrm{mg}, 1.57 \mathrm{mmol})$ in dry $\mathrm{CH}_{2} \mathrm{Cl}_{2}$, was cooled to $0{ }^{\circ} \mathrm{C}$. Then, MeOTf $(219$ $\mu \mathrm{L}, 1.89 \mathrm{mmol}$ ) was added, and the mixture was stirred for $8 \mathrm{~h}$ at room temperature. All volatiles were removed under reduced pressure to yield $\mathbf{3}$ as an analytically pure light brown solid (523 mg, 94\%). ${ }^{1} \mathrm{H}$ NMR (300 MHz, $\left.\mathrm{CD}_{3} \mathrm{CN}\right): \delta 9.53$ (s, $1 \mathrm{H}, \mathrm{H}_{\text {trz }}$ ), 8.69 (d, ${ }^{3} \mathrm{~J}_{\mathrm{HH}}=5.1 \mathrm{~Hz}, 1 \mathrm{H}, \mathrm{H}_{\mathrm{py}}$ ), 8.26-8.18 (m, 1H, $\left.\mathrm{H}_{\mathrm{py}}\right), 8.14-8.08\left(\mathrm{~m}, 1 \mathrm{H}, \mathrm{H}_{\mathrm{py}}\right), 7.79-7.72\left(\mathrm{~m}, 1 \mathrm{H}, \mathrm{H}_{\mathrm{py}}\right), 6.53$ (broad s, OH) 4.59 
(s, 3H, NCH 3$) .{ }^{13} \mathrm{C}\left\{{ }^{1} \mathrm{H}\right\} \mathrm{NMR}\left(101 \mathrm{MHz}, \mathrm{CD}_{3} \mathrm{CN}\right): \delta 156.2(\mathrm{COO}), 150.6\left(\mathrm{C}_{\mathrm{py}} \mathrm{H}\right), 147.3\left(\mathrm{C}_{\mathrm{py}}-\mathrm{N}\right)$, $142.0\left(\mathrm{C}_{\mathrm{py}} \mathrm{H}\right), 135.2\left(\mathrm{C}_{\mathrm{trz}}-\mathrm{COO}\right), 130.5\left(\mathrm{C}_{\mathrm{trz}} \mathrm{H}\right), 128.7\left(\mathrm{C}_{\mathrm{py}} \mathrm{H}\right), 116.0\left(\mathrm{C}_{\mathrm{py}} \mathrm{H}\right), 42.4\left(\mathrm{NCH}_{3}\right)$. Anal. Calcd. for $\mathrm{C}_{10} \mathrm{H}_{9} \mathrm{~F}_{3} \mathrm{~N}_{4} \mathrm{O}_{5} \mathrm{~S}\left(354.26 \mathrm{~g} \mathrm{~mol}^{-1}\right)$ : C, 33.90; H, 2.56; N, 15.81. Found: C, 34.30; H, 2.07; N, 16.27. ESI-MS (Cone 15V): $205.0[\mathrm{M}-\mathrm{OTf}]^{+}$. IR $\left(\mathrm{CH}_{3} \mathrm{CN}\right): v=1746 \mathrm{~cm}^{-1}(\mathrm{C}=\mathrm{O})$.

Synthesis of [RuCl(cym)(N,C-pyr-trz]OTf 4. The triazolium salt 3 (174 $\mathrm{mg}, 0.491 \mathrm{mmol})$ and $\mathrm{Ag}_{2} \mathrm{O}$ (342 mg, $\left.1.47 \mathrm{mmol}\right)$ were suspended in $\mathrm{MeCN}(10 \mathrm{~mL})$, protected from light, and stirred for 3 days. Then $\left[\mathrm{RuCl}_{2}(p \text {-cymene) }]_{2}(150 \mathrm{mg}, 0.245 \mathrm{mmol})\right.$ was added and the reaction mixture was stirred at room temperature for $15 \mathrm{~h}$. The resulting suspension was filtered through Celite and the volatiles were evaporated under reduced pressure. The crude solid was purified by column chromatography $\left(\mathrm{SiO}_{2} ; \mathrm{CH}_{2} \mathrm{Cl}_{2} /\right.$ Acetone 1:1). The orange fraction was collected and evaporated to dryness, and then precipitated with $\mathrm{MeCN} / \mathrm{Et}_{2} \mathrm{O}$, thus affording an analytically pure orange solid (80 mg, 28\%). ${ }^{1} \mathrm{H}$ NMR $\left(400 \mathrm{MHz}, \mathrm{CD}_{3} \mathrm{CN}\right): \delta 9.25\left(\mathrm{dd}, \mathrm{J}_{\mathrm{HH}}=5.7,0.8 \mathrm{~Hz}, 1 \mathrm{H}\right.$, $\left.\mathrm{H}_{\mathrm{py}}\right), 8.42\left(\mathrm{~s}, 1 \mathrm{H}, \mathrm{H}_{\text {trz }}\right), 8.29-8.17\left(\mathrm{~m}, 1 \mathrm{H}, \mathrm{H}_{\mathrm{py}}\right), 8.15-8.07$ (m, $\left.1 \mathrm{H}, \mathrm{H}_{\mathrm{py}}\right), 7.72-7.59$ (m, $1 \mathrm{H}, \mathrm{H}_{\mathrm{py}}$ ), 6.06, 5.88, 5.70, $5.50\left(4 \times \mathrm{d},{ }^{3} \mathrm{~J}_{\mathrm{HH}}=6.1 \mathrm{~Hz}, 1 \mathrm{H}, \mathrm{H}_{\mathrm{cym}}\right), 4.33\left(\mathrm{~s}, 3 \mathrm{H}, \mathrm{NCH}_{3}\right), 2.69-2.52(\mathrm{~m}, 1 \mathrm{H}$, $\left.\mathrm{CHMe}_{2}\right), 2.04$ (s, 3H, $\left.\mathrm{C}_{\mathrm{cym}}-\mathrm{CH}_{3}\right), 1.12,1.01\left(2 \times \mathrm{d},{ }^{3} \mathrm{~J}_{\mathrm{HH}}=6.9 \mathrm{~Hz}, 3 \mathrm{H}, \mathrm{CH}-\mathrm{CH}\right) .{ }^{13} \mathrm{C}\left\{{ }^{1} \mathrm{H}\right\} \mathrm{NMR}$ $\left(101 \mathrm{MHz}, \mathrm{CD}_{3} \mathrm{CN}\right): \delta 171.5\left(\mathrm{C}_{\mathrm{trz}}-\mathrm{Ru}\right), 156.8\left(\mathrm{C}_{\mathrm{py}} \mathrm{H}\right), 150.8\left(\mathrm{C}_{\mathrm{py}}-\mathrm{N}\right), 142.9\left(\mathrm{C}_{\mathrm{py}} \mathrm{H}\right), 136.9$ $\left(\mathrm{C}_{\text {trz }} \mathrm{H}\right), 127.2\left(\mathrm{C}_{\mathrm{py}} \mathrm{H}\right), 115.1\left(\mathrm{C}_{\mathrm{py}} \mathrm{H}\right), 108.0,104.2\left(2 \times C_{\text {cym }}-\mathrm{C}\right), 90.7,89.5,85.9,85.3(4 \times$ $\left.\mathrm{C}_{\text {cym }} \mathrm{H}\right), 40.6\left(\mathrm{NCH}_{3}\right), 31.8\left(\mathrm{CHMe}_{2}\right), 22.6,22.0\left(2 \times \mathrm{CH}-\mathrm{CH}_{3}\right), 18.8\left(\mathrm{C}_{\mathrm{cym}}-\mathrm{CH}_{3}\right)$. Anal. Calcd. for $\mathrm{C}_{19} \mathrm{H}_{22} \mathrm{ClF}_{3} \mathrm{~N}_{4} \mathrm{O}_{3} \mathrm{RuS}\left(579.98 \mathrm{~g} \mathrm{~mol}^{-1}\right)$ : C, 39.34; H, 3.82; N, 9.66. Found: C, 39.22; H, 3.70; N, 9.41. ESI-MS (Cone 20V): 431.43 [M-OTf] ${ }^{+}$.

Synthesis of [RuCl(cym)(MeCN)(C-pyr-trz]OTf 5. Under exclusion of light, the triazolium salt 3 (174 mg, $0.491 \mathrm{mmol})$ and $\mathrm{Ag}_{2} \mathrm{O}$ (228 mg, $\left.0.982 \mathrm{mmol}\right)$ were suspended in $\mathrm{MeCN}(10 \mathrm{~mL})$ and stirred for $2 \mathrm{~h}$. Then $\left[\mathrm{RuCl}_{2}(p \text {-cymene })\right]_{2}(150 \mathrm{mg}, 0,245 \mathrm{mmol})$ was added and the reaction mixture was stirred at room temperature for $3 \mathrm{~h}$. The resulting suspension was filtered through Celite and the solvent was evaporated under reduced pressure. The crude solid was purified by column chromatography $\left(\mathrm{SiO}_{2} ; \mathrm{CH}_{2} \mathrm{Cl}_{2} /\right.$ Acetone 1:1). The orange band was collected and evaporated to dryness. The residue was redissolved in $\mathrm{MeCN}$ and precipitated by addition of $\mathrm{Et}_{2} \mathrm{O}$ to afford complex 5 as an analytically pure orange solid. Yield: $85 \mathrm{mg}, 28 \%$. ${ }^{1} \mathrm{H}$ NMR (400 $\mathrm{MHz}, \mathrm{CD}_{3} \mathrm{CN}$ ): $\delta 8.63$ (ddd, $\left.\mathrm{J}_{\mathrm{HH}}=4.8,1.8,0.8 \mathrm{~Hz}, 1 \mathrm{H}, \mathrm{H}_{\mathrm{py}}\right), 8.43\left(\mathrm{~s}, 1 \mathrm{H}, \mathrm{H}_{\mathrm{trz}}\right), 8.16-8.10(\mathrm{~m}, 1 \mathrm{H}$, $\left.\mathrm{H}_{\mathrm{py}}\right), 8.02-7.98\left(\mathrm{~m}, 1 \mathrm{H}, \mathrm{H}_{\mathrm{py}}\right), 7.66-7.61\left(\mathrm{~m}, 1 \mathrm{H}, \mathrm{H}_{\mathrm{py}}\right), 5.75,5.68,5.62,5.48\left(4 \times \mathrm{d},{ }^{3} \mathrm{~J}_{\mathrm{HH}}=6.1 \mathrm{~Hz}\right.$, $\left.1 \mathrm{H}, \mathrm{H}_{\mathrm{cym}}\right), 4.36\left(\mathrm{~s}, 3 \mathrm{H}, \mathrm{NCH}_{3}\right), 2.78-2.66\left(\mathrm{~m}, 1 \mathrm{H}, \mathrm{CHMe}_{2}\right), 2.26\left(\mathrm{~s}, 3 \mathrm{H}, \mathrm{CH}_{3} \mathrm{CN}\right), 2.09(\mathrm{~s}, 3 \mathrm{H}$, $\left.\mathrm{C}_{\mathrm{cym}}-\mathrm{CH}_{3}\right), 1.24,1.23\left(2 \times \mathrm{d},{ }^{3} \mathrm{~J}_{\mathrm{HH}}=5.1 \mathrm{~Hz}, 3 \mathrm{H}, \mathrm{CH}-\mathrm{CH}_{3}\right) .{ }^{13} \mathrm{C}\left\{{ }^{1} \mathrm{H}\right\} \mathrm{NMR}\left(101 \mathrm{MHz}, \mathrm{CD}_{3} \mathrm{CN}\right)$ : $\delta 161.4\left(\mathrm{C}_{\mathrm{trz}}-\mathrm{Ru}\right), 149.9\left(\mathrm{C}_{\mathrm{py}} \mathrm{H}\right), 148.0\left(\mathrm{C}_{\mathrm{py}}-\mathrm{N}\right), 141.1\left(\mathrm{C}_{\mathrm{py}} \mathrm{H}\right), 130.7\left(\mathrm{C}_{\mathrm{trz}} \mathrm{H}\right), 126.9,115.4(2 \times$ $\left.\mathrm{C}_{\mathrm{py}} \mathrm{H}\right), 108.9,102.6\left(2 \times C_{\text {cym- }} \mathrm{C}\right), 88.0,87.8,87.2,85.0\left(4 \times \mathrm{C}_{\text {cym }} \mathrm{H}\right), 41.8\left(\mathrm{NCH}_{3}\right), 31.3(\mathrm{CHMe})$, 22.2, $22.0\left(2 \times \mathrm{CH}-\mathrm{CH}_{3}\right), 18.2\left(\mathrm{C}_{\text {cym }}-\mathrm{CH}_{3}\right)$. Anal. Calcd. for $\mathrm{C}_{21} \mathrm{H}_{25} \mathrm{~F}_{3} \mathrm{~N}_{5} \mathrm{O}_{3} \mathrm{RuS}\left(621.04 \mathrm{~g} \mathrm{~mol}^{-1}\right)$ : 
C, 40.61; H, 4.06; N, 11.27. Found: C, 40.34; H, 4.42; N, 10.87. ESI-MS (Cone 20V): 472.47 $[\mathrm{M}-\mathrm{OTf}]^{+}$.

Synthesis of $\left[\mathbf{R u C l}_{\mathbf{2}}(\mathbf{c y m})\left(\boldsymbol{C}\right.\right.$-pyr-trz] 6. A solution of $\mathbf{5}(50 \mathrm{mg}, 0.08 \mathrm{mmol})$ in $\mathrm{CDCl}_{3}(0.8 \mathrm{~mL})$ was left standing for $1 \mathrm{~h}$, which produced a mixture of 5 and $\mathbf{6}$ according to ${ }^{1} \mathrm{H}$ NMR spectroscopy. Complex 6 was separated by column chromatography $\left(\mathrm{SiO}_{2} ; \mathrm{CH}_{2} \mathrm{Cl}_{2} /\right.$ Acetone 8:2). An orange band separated and was collected and evaporated to dryness. Subsequent crystallization by slow diffusion of pentane in a concentrated solution of $\mathbf{6}$ in $\mathrm{CHCl}_{3}$ gave an analytically pure sample of $\mathbf{6}(17 \mathrm{mg}, 45 \%)$ and crystals suitable for X-ray diffraction analysis. ${ }^{1} \mathrm{H}$ NMR $\left(400 \mathrm{MHz}, \mathrm{CD}_{3} \mathrm{CN}\right): \delta 8.63-8.60\left(\mathrm{~m}, 1 \mathrm{H}, \mathrm{H}_{\mathrm{py}}\right), 8.44\left(\mathrm{~s}, 1 \mathrm{H}, \mathrm{H}_{\mathrm{trz}}\right), 8.12-8.07(\mathrm{~m}, 1 \mathrm{H}$, $\left.\mathrm{H}_{\mathrm{py}}\right), 7.99-7.95\left(\mathrm{~m}, 1 \mathrm{H}, \mathrm{H}_{\mathrm{py}}\right), 7.62-7.57\left(\mathrm{~m}, 1 \mathrm{H}, \mathrm{H}_{\mathrm{py}}\right), 5.42,5.28\left(2 \times \mathrm{d},{ }^{3} \mathrm{~J}_{\mathrm{HH}}=6.0 \mathrm{~Hz}, 2 \mathrm{H}, \mathrm{H}_{\mathrm{cym}}\right)$, $4.45\left(\mathrm{~s}, 3 \mathrm{H}, \mathrm{NCH}_{3}\right), 2.79-2.65\left(\mathrm{~m}, 1 \mathrm{H}, \mathrm{CHMe}_{2}\right), 2.10\left(\mathrm{~s}, 3 \mathrm{H}, \mathrm{C}_{\mathrm{cym}}-\mathrm{CH}_{3}\right), 1.22\left(\mathrm{~d},{ }^{3} \mathrm{~J}_{\mathrm{HH}}=7.2 \mathrm{~Hz}\right.$, $\left.6 \mathrm{H}, \mathrm{CH}-\mathrm{CH}_{3}\right) .{ }^{13} \mathrm{C}\left\{{ }^{1} \mathrm{H}\right\}$ NMR $\left(101 \mathrm{MHz}, \mathrm{CD}_{3} \mathrm{CN}\right): \delta 167.8\left(\mathrm{C}_{\mathrm{trz}}-\mathrm{Ru}\right), 150.0\left(\mathrm{C}_{\mathrm{py}} \mathrm{H}\right), 148.5\left(\mathrm{C}_{\mathrm{py}}-\right.$ $\mathrm{N}), 141.2\left(\mathrm{C}_{\mathrm{py}} \mathrm{H}\right), 130.9\left(\mathrm{C}_{\mathrm{trz}} \mathrm{H}\right), 126.7\left(\mathrm{C}_{\mathrm{py}} \mathrm{H}\right), 115.4\left(\mathrm{C}_{\mathrm{py}} \mathrm{H}\right), 104.1,100.4\left(2 \times C_{\mathrm{cym}}-\mathrm{C}\right), 85.5$, $84.9\left(2 \times \mathrm{C}_{\mathrm{cym}} \mathrm{H}\right), 41.9\left(\mathrm{NCH}_{3}\right), 31.4\left(\mathrm{CHMe}_{2}\right), 22.5\left(\mathrm{CH}-\mathrm{CH}_{3}\right), 18.5\left(\mathrm{C}_{\mathrm{cym}}-\mathrm{CH}_{3}\right)$. Anal. Calcd. for $\mathrm{C}_{18} \mathrm{H}_{22} \mathrm{Cl}_{2} \mathrm{~N}_{4} \mathrm{Ru}\left(466.37 \mathrm{~g} \mathrm{~mol}^{-1}\right)$ : C, 46.35; H, 4.75; N, 12.01. Found: $\mathrm{C}, 46.85 ; \mathrm{H}, 4.42 ; \mathrm{N}$, 11.94. ESI-MS (Cone 20V): $431.48[\mathrm{M}-\mathrm{Cl}]^{+}$.

Synthesis of pyr-trzH(OTf)-COOEt 8. A solution of ethyl-1-(2-pyridyl)-1H-1,2,3-triazole-4carboxylate $1(500 \mathrm{mg}, 2.29 \mathrm{mmol})$ in dry $\mathrm{CH}_{2} \mathrm{Cl}_{2}$, was cooled to $0{ }^{\circ} \mathrm{C}$. Then, MeOTf $(318 \mu \mathrm{L}$, $2.75 \mathrm{mmol}$ ) was added, and the mixture was stirred for $1 \mathrm{~h}$ at room temperature. All volatiles were removed under reduced pressure to afford an analytically pure light brown solid (779 $\mathrm{mg}$, 89\%). ${ }^{1} \mathrm{H}$ NMR (400 MHz, $\left.\mathrm{CD}_{3} \mathrm{CN}\right): \delta 9.54\left(\mathrm{~s}, 1 \mathrm{H}, \mathrm{H}_{\mathrm{trz}}\right), 8.69\left(\mathrm{ddd},{ }^{3} \mathrm{~J}_{\mathrm{HH}}=4.8 \mathrm{~Hz},{ }^{4} \mathrm{~J}_{\mathrm{HH}}=1.8 \mathrm{~Hz}\right.$, $\left.{ }^{5} \mathrm{~J}_{\mathrm{HH}}=0.9 \mathrm{~Hz}, 1 \mathrm{H}, \mathrm{H}_{\mathrm{py}}\right), 8.28-8.19\left(\mathrm{~m}, 1 \mathrm{H}, \mathrm{H}_{\mathrm{py}}\right), 8.19-8.07\left(\mathrm{~m}, 1 \mathrm{H}, \mathrm{H}_{\mathrm{py}}\right), 7.83-7.68\left(\mathrm{~m}, 1 \mathrm{H}, \mathrm{H}_{\mathrm{py}}\right)$, $4.60\left(\mathrm{~s}, 3 \mathrm{H}, \mathrm{NCH}_{3}\right), 4.53\left(\mathrm{q},{ }^{3} \mathrm{~J}_{\mathrm{HH}}=7.1 \mathrm{~Hz}, 2 \mathrm{H}, \mathrm{OCH}_{2}\right), 1.44\left(\mathrm{t},{ }^{3} \mathrm{~J}_{\mathrm{HH}}=7.1 \mathrm{~Hz}, 3 \mathrm{H}, \mathrm{OCH}_{2} \mathrm{CH}_{3}\right)$. ${ }^{13} \mathrm{C}\left\{{ }^{1} \mathrm{H}\right\}$ NMR $\left(101 \mathrm{MHz}, \mathrm{CD}_{3} \mathrm{CN}\right): \delta 155.0(\mathrm{COO}), 150.6\left(\mathrm{C}_{\mathrm{py}} \mathrm{H}\right), 147.3\left(\mathrm{C}_{\mathrm{py}}-\mathrm{N}\right), 142.1\left(\mathrm{C}_{\mathrm{py}} \mathrm{H}\right)$, $135.2\left(C_{\text {trz }}-\mathrm{COO}\right), 130.4\left(\mathrm{C}_{\mathrm{trz}} \mathrm{H}\right), 128.7\left(\mathrm{C}_{\mathrm{py}} \mathrm{H}\right), 116.0\left(\mathrm{C}_{\mathrm{py}} \mathrm{H}\right), 65.1\left(\mathrm{OCH}_{2}\right), 42.4\left(\mathrm{NCH}_{3}\right), 14.1$ $\left(\mathrm{OCH}_{2} \mathrm{CH}_{3}\right)$. Anal. Calcd. for $\mathrm{C}_{12} \mathrm{H}_{13} \mathrm{~F}_{3} \mathrm{~N}_{4} \mathrm{O}_{5} \mathrm{~S}\left(382.31 \mathrm{~g} \mathrm{~mol}^{-1}\right)$ : C, 37.70; H, 3.42; N, 14.65. Found: C, 37.68; H, 2.98; N, 14.67. ESI-MS (Cone 15V): $233.4[\mathrm{M}-\mathrm{OTf}]^{+}$.

Synthesis of [RuCl(cym)( $\boldsymbol{N}, \boldsymbol{C}$-pyr-trz-COOEt]OTf 9. The triazolium salt 8 (300 mg, 0.784 $\mathrm{mmol})$ and $\mathrm{Ag}_{2} \mathrm{O}(272 \mathrm{mg}, 1.18 \mathrm{mmol})$ were suspended in $\mathrm{CH}_{2} \mathrm{Cl}_{2}(10 \mathrm{~mL})$ and stirred under exclusion of light for $24 \mathrm{~h}$. Then $\left[\mathrm{RuCl}_{2}(p \text {-cymene })\right]_{2}(235 \mathrm{mg}, 0,384 \mathrm{mmol})$ was added and the reaction mixture was stirred at room temperature for $12 \mathrm{~h}$, subsequently filtered through Celite and the all volatiles evaporated under reduced pressure. The crude solid was purified by column chromatography $\left(\mathrm{SiO}_{2} ; \mathrm{CH}_{2} \mathrm{Cl}_{2} / \mathrm{MeOH} 40: 1\right)$. An orange band separated and was collected and evaporated. Precipitation with $\mathrm{MeCN} / \mathrm{Et}_{2} \mathrm{O}$ gave an analytically pure orange solid $(385 \mathrm{mg}$, 77\%). ${ }^{1} \mathrm{H}$ NMR (400 MHz, $\left.\mathrm{CD}_{3} \mathrm{CN}\right): \delta 9.27\left(\mathrm{~d},{ }^{3} \mathrm{~J}_{\mathrm{HH}}=5.7 \mathrm{~Hz}, 1 \mathrm{H}, \mathrm{H}_{\mathrm{py}}\right), 8.30-8.23\left(\mathrm{~m}, 1 \mathrm{H}, \mathrm{H}_{\mathrm{py}}\right)$, 
8.19-8.14 (m, 1H, $\left.\mathrm{H}_{\mathrm{py}}\right), 7.73-7.65\left(\mathrm{~m}, 1 \mathrm{H}, \mathrm{H}_{\mathrm{py}}\right), 6.23\left(\mathrm{~d},{ }^{3} \mathrm{~J}_{\mathrm{HH}}=6.1 \mathrm{~Hz}, 1 \mathrm{H}, \mathrm{H}_{\mathrm{cym}}\right), 6.15,5.82(2 \times$ $\left.\mathrm{d},{ }^{3} \mathrm{~J}_{\mathrm{HH}}=6.2 \mathrm{~Hz}, 1 \mathrm{H}, \mathrm{H}_{\mathrm{cym}}\right), 5.43\left(\mathrm{~d},{ }^{3} \mathrm{~J}_{\mathrm{HH}}=6.1 \mathrm{~Hz}, 1 \mathrm{H}, \mathrm{H}_{\mathrm{cym}}\right), 4.66-4.57\left(\mathrm{~m}, 2 \mathrm{H}, \mathrm{OCH}_{2}\right), 4.53(\mathrm{~s}$, $\left.3 \mathrm{H}, \mathrm{NCH}_{3}\right), 2.56-2.43(\mathrm{~m}, 1 \mathrm{H}, \mathrm{CHMe}), 2.12\left(\mathrm{~s}, 3 \mathrm{H}, \mathrm{C}_{\mathrm{cym}}-\mathrm{CH}_{3}\right), 1.51\left(\mathrm{t},{ }^{3} \mathrm{~J}_{\mathrm{HH}}=7.1 \mathrm{~Hz}, 3 \mathrm{H}\right.$, $\left.\mathrm{OCH}_{2} \mathrm{CH}_{3}\right), 1.01,0.90\left(2 \times \mathrm{d},{ }^{3} \mathrm{~J}_{\mathrm{HH}}=6.9 \mathrm{~Hz}, 3 \mathrm{H}, \mathrm{CH}-\mathrm{CH}_{3}\right) .{ }^{13} \mathrm{C}\left\{{ }^{1} \mathrm{H}\right\} \mathrm{NMR}\left(101 \mathrm{MHz}, \mathrm{CD}_{3} \mathrm{CN}\right)$ : $\delta 177.1\left(\mathrm{C}_{\mathrm{trz}}-\mathrm{Ru}\right), 159.2(\mathrm{COO}), 156.8\left(\mathrm{C}_{\mathrm{py}} \mathrm{H}\right), 150.5\left(\mathrm{C}_{\mathrm{py}}-\mathrm{N}\right), 143.1\left(\mathrm{C}_{\mathrm{py}} \mathrm{H}\right), 139.8\left(C_{\mathrm{trz}}-\mathrm{COO}\right)$, $127.6\left(\mathrm{C}_{\text {py }} \mathrm{H}\right), 115.4\left(\mathrm{C}_{\text {py }} \mathrm{H}\right), 108.7,107.9\left(2 \times C_{\text {cym }}-\mathrm{C}\right), 91.1,89.4,89.0,83.2\left(4 \times \mathrm{C}_{\text {cym }} \mathrm{H}\right), 64.2$ $\left(\mathrm{OCH}_{2}\right), 43.3\left(\mathrm{NCH}_{3}\right), 31.9\left(\mathrm{CHMe}_{2}\right), 22.6,22.5\left(2 \times \mathrm{CH}-\mathrm{CH}_{3}\right), 19.3\left(\mathrm{C}_{\mathrm{cym}}-\mathrm{CH}_{3}\right), 14.5$ $\left(\mathrm{OCH}_{2} \mathrm{CH}_{3}\right)$. Anal. Calcd. for $\mathrm{C}_{22} \mathrm{H}_{26} \mathrm{~F}_{3} \mathrm{ClN}_{4} \mathrm{O}_{5} \mathrm{RuS}\left(652.05 \mathrm{~g} \mathrm{~mol}^{-1}\right)$ : C, 40.51; H, 4.02; N, 8.59. Found: C, 39.99; H, 3.79; N, 8.62. ESI-MS (Cone 20V): $502.3[\mathrm{M}-\mathrm{OTf}]^{+}$. IR $\left(\mathrm{CH}_{3} \mathrm{CN}\right): v=1729$ $\mathrm{cm}^{-1}(\mathrm{C}=\mathrm{O})$.

Synthesis of $[\mathrm{RuCl}(\mathbf{c y m})(\boldsymbol{N}, \boldsymbol{C}$-pyr-trz-COO] 10. A mixture of complex 9 (100 mg, 0.153 $\mathrm{mmol})$ and $\mathrm{LiOH} \cdot \mathrm{H}_{2} \mathrm{O}(14 \mathrm{mg}, 0.306 \mathrm{mmol})$ in $\mathrm{MeOH} / \mathrm{H}_{2} \mathrm{O}(5 \mathrm{~mL} ; 1: 1)$ was stirred for $3 \mathrm{~h}$ at 30 ${ }^{\circ} \mathrm{C}$. The reaction mixture was extracted with $\mathrm{CH}_{2} \mathrm{Cl}_{2} / \mathrm{H}_{2} \mathrm{O}$ and the aqueous layers were combined and the solvent was removed under reduced pressure. The crude residue was dissolved in $\mathrm{MeCN}$ and filtered through Celite. Precipitation with $\mathrm{Et}_{2} \mathrm{O}$ afforded an analytically pure orange solid. Yield: $60 \mathrm{mg}, 83 \%$. ${ }^{1} \mathrm{H}$ NMR $\left(300 \mathrm{MHz}, \mathrm{CD}_{3} \mathrm{CN}\right): \delta 9.28\left(\mathrm{~d},{ }^{3} \mathrm{~J}_{\mathrm{HH}}=5.3 \mathrm{~Hz}, 1 \mathrm{H}, \mathrm{H}_{\mathrm{py}}\right), 8.25-8.19$ $\left(\mathrm{m}, 1 \mathrm{H}, \mathrm{H}_{\mathrm{py}}\right), 8.14-8.09\left(\mathrm{~m}, 1 \mathrm{H}, \mathrm{H}_{\mathrm{py}}\right), 7.66-7.61\left(\mathrm{~m}, 1 \mathrm{H}, \mathrm{H}_{\mathrm{py}}\right), 6.53\left(\mathrm{~d},{ }^{3} \mathrm{~J}_{\mathrm{HH}}=5.8 \mathrm{~Hz}, 1 \mathrm{H}, \mathrm{H}_{\mathrm{cym}}\right)$, $6.25,5.78\left(2 \times \mathrm{d},{ }^{3} \mathrm{~J}_{\mathrm{HH}}=6.1 \mathrm{~Hz}, 1 \mathrm{H}, \mathrm{H}_{\text {cym }}\right), 5.54\left(\mathrm{~d},{ }^{3} \mathrm{~J}_{\mathrm{HH}}=5.8 \mathrm{~Hz}, 1 \mathrm{H}, \mathrm{H}_{\text {cym }}\right), 4.59\left(\mathrm{~s}, 3 \mathrm{H}, \mathrm{NCH}_{3}\right)$, 2.54-2.42 (m, 1H, CHMe 2$), 2.09\left(\mathrm{~s}, 3 \mathrm{H}, \mathrm{C}_{\mathrm{cym}}-\mathrm{CH}_{3}\right), 0.98,0.85\left(2 \times \mathrm{d},{ }^{3} \mathrm{~J}_{\mathrm{HH}}=6.9 \mathrm{~Hz}, 3 \mathrm{H}, \mathrm{CH}-\right.$ $\left.\mathrm{CH}_{3}\right) .{ }^{13} \mathrm{C}\left\{{ }^{1} \mathrm{H}\right\}$ NMR (101 MHz, $\left.\mathrm{CD}_{3} \mathrm{CN}\right): \delta 172.3\left(\mathrm{C}_{\mathrm{trz}}-\mathrm{Ru}\right), 162.6(\mathrm{COO}), 156.7\left(\mathrm{C}_{\mathrm{py}} \mathrm{H}\right), 151.1$ $\left(\mathrm{C}_{\mathrm{py}} \mathrm{H}\right), 150.5\left(\mathrm{C}_{\mathrm{py}}-\mathrm{N}\right), 146.0\left(C_{\mathrm{trz}}-\mathrm{COO}\right), 142.6,126.9,114.9\left(3 \times \mathrm{C}_{\mathrm{py}} \mathrm{H}\right), 108.0,106.4(2 \times$ $\left.C_{\text {cym }}-\mathrm{C}\right), 90.9,90.3,88.5,82.5\left(4 \times \mathrm{C}_{\text {cym }} \mathrm{H}\right), 41.9\left(\mathrm{NCH}_{3}\right), 31.9\left(\mathrm{CHMe}_{2}\right), 22.7\left(\mathrm{CH}-\mathrm{CH}_{3}\right), 19.5$ $\left(\mathrm{C}_{\mathrm{cym}}-\mathrm{CH}_{3}\right)$. Attempts to obtain satisfactory elemental analysis of $\mathbf{1 0}$ failed, probably because this species is highly hygroscopic. ESI-MS (Cone 20V): $439.0[\mathrm{M}-\mathrm{Cl}]^{+}$. IR $\left(\mathrm{CH}_{3} \mathrm{CN}\right): v=1618 \mathrm{~cm}^{-1}$ $(\mathrm{C}=\mathrm{O})$.

Synthesis of [RuCl(cym)(N,C-pyr-trz-COOH]OTf 11. Complex 9 (100 mg, $0.153 \mathrm{mmol})$ and $\mathrm{LiOH} \cdot \mathrm{H}_{2} \mathrm{O}(14 \mathrm{mg}, 0.306 \mathrm{mmol})$ in a $\mathrm{MeOH} / \mathrm{H}_{2} \mathrm{O}$ mixture $(5 \mathrm{~mL} ; 1: 1)$ were stirred for $3 \mathrm{~h}$ at 30 ${ }^{\circ} \mathrm{C}$. The reaction mixture was acidified with aqueous $\mathrm{HCl}(1 \mathrm{M})$ and extracted with $\mathrm{CH}_{2} \mathrm{Cl}_{2} / \mathrm{H}_{2} \mathrm{O}$ mixtures. The organic layers were combined and the solvent was removed under reduced pressure. After precipitation with $\mathrm{MeCN} / \mathrm{Et}_{2} \mathrm{O}$, complex 11 was isolated as an analytically pure orange solid (88 mg, 92\%). ${ }^{1} \mathrm{H} \mathrm{NMR}\left(400 \mathrm{MHz}, \mathrm{CD}_{3} \mathrm{CN}\right): \delta 9.29\left(\mathrm{~d},{ }^{3} \mathrm{~J}_{\mathrm{HH}}=5.6 \mathrm{~Hz}, 1 \mathrm{H}, \mathrm{H}_{\mathrm{py}}\right.$ ), 8.26-8.21 (m, 1H, $\left.\mathrm{H}_{\mathrm{py}}\right), 8.16-8.12\left(\mathrm{~m}, 1 \mathrm{H}, \mathrm{H}_{\mathrm{py}}\right), 7.68-7.63\left(\mathrm{~m}, 1 \mathrm{H}, \mathrm{H}_{\mathrm{py}}\right), 6.41,6.19,5.89,5.61$ (4 $\left.\times \mathrm{d},{ }^{3} \mathrm{~J}_{\mathrm{HH}}=6.0 \mathrm{~Hz}, 1 \mathrm{H}, \mathrm{H}_{\mathrm{cym}}\right), 4.57\left(\mathrm{~s}, 3 \mathrm{H}, \mathrm{NCH}_{3}\right), 4.20($ broad s, $1 \mathrm{H}, \mathrm{OH}), 2.57-2.43(\mathrm{~m}, 1 \mathrm{H}$, $\left.\mathrm{CHMe}_{2}\right), 2.13\left(\mathrm{~s}, 3 \mathrm{H}, \mathrm{C}_{\mathrm{cym}}-\mathrm{CH}_{3}\right), 0.98,0.91\left(2 \times \mathrm{d},{ }^{3} \mathrm{~J}_{\mathrm{HH}}=6.9 \mathrm{~Hz}, 3 \mathrm{H}, \mathrm{CH}-\mathrm{CH}_{3}\right) .{ }^{13} \mathrm{C}\left\{{ }^{1} \mathrm{H}\right\} \mathrm{NMR}$ $\left(101 \mathrm{MHz}, \mathrm{CD}_{3} \mathrm{CN}\right): \delta 174.9\left(\mathrm{C}_{\mathrm{trz}}-\mathrm{Ru}\right), 161.4(\mathrm{COO}), 156.8\left(\mathrm{C}_{\mathrm{py}} \mathrm{H}\right), 150.8\left(\mathrm{C}_{\mathrm{py}}-\mathrm{N}\right), 142.8$ 
$\left(\mathrm{C}_{\mathrm{py}} \mathrm{H}\right), 142.5\left(C_{\mathrm{trz}}-\mathrm{C}\right), 127.3,115.2\left(2 \times \mathrm{C}_{\mathrm{py}} \mathrm{H}\right), 108.1,106.9\left(2 \times C_{\text {cym }}-\mathrm{C}\right), 91.2,89.7,89.2,83.6$ $\left(4 \times \mathrm{C}_{\text {cym }} \mathrm{H}\right), 42.3\left(\mathrm{NCH}_{3}\right), 31.9\left(\mathrm{CHMe}_{2}\right), 22.6\left(\mathrm{CH}-\mathrm{CH}_{3}\right), 19.3\left(\mathrm{C}_{\mathrm{cym}}-\mathrm{CH}_{3}\right)$. Anal. Calcd. for $\mathrm{C}_{20} \mathrm{H}_{22} \mathrm{ClF}_{3} \mathrm{~N}_{4} \mathrm{O}_{5} \mathrm{Ru}\left(623.99 \mathrm{~g} \mathrm{~mol}^{-1}\right)$ : C, 38.50; H, 3.55; N, 8.98. Found: C, 38.49; H, 3.41; N, 8.92. ESI-MS (Cone 20V): $475.7[\mathrm{M}-\mathrm{OTf}]^{+}$. IR $\left(\mathrm{CH}_{3} \mathrm{CN}\right) v=1735.5 \mathrm{~cm}^{-1}(\mathrm{C}=\mathrm{O})$.

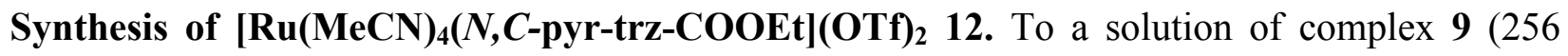
$\mathrm{mg}, 0.402 \mathrm{mmol})$ in $\mathrm{MeCN}(10 \mathrm{~mL})$ was added AgOTf $(157 \mathrm{mg}, 0.603 \mathrm{mmol})$, and the suspension was stirred at reflux for $24 \mathrm{~h}$. The reaction mixture was filtered through Celite and the solvent was removed under reduced pressure. Precipitation with $\mathrm{MeCN}_{2} / \mathrm{Et}_{2} \mathrm{O}$ afforded a spectroscopically pure yellow solid. Yield: $240 \mathrm{mg}, 75 \%$. ${ }^{1} \mathrm{H}$ NMR $\left(400 \mathrm{MHz}, \mathrm{CD}_{3} \mathrm{CN}\right): \delta 9.00-$ $8.97\left(\mathrm{~m}, 1 \mathrm{H}, \mathrm{H}_{\mathrm{py}}\right), 8.24-8.21\left(\mathrm{~m}, 2 \mathrm{H}, \mathrm{H}_{\mathrm{py}}\right), 7.70-7.65\left(\mathrm{~m}, 1 \mathrm{H}, \mathrm{H}_{\mathrm{py}}\right), 4.57-4.49\left(\mathrm{~m}, 5 \mathrm{H}, \mathrm{NCH}_{3}\right.$, $\left.\mathrm{OCH}_{2}\right), 2.50\left(\mathrm{~s}, 3 \mathrm{H}, \mathrm{CH}_{3} \mathrm{CN}\right), 2.08\left(\mathrm{~s}, 6 \mathrm{H}, \mathrm{CH}_{3} \mathrm{CN}\right), 1.45\left(\mathrm{t},{ }^{3} \mathrm{~J}_{\mathrm{HH}}=7.1 \mathrm{~Hz}, 3 \mathrm{H}, \mathrm{OCH}_{2} \mathrm{CH}_{3}\right)$. ${ }^{13} \mathrm{C}\left\{{ }^{1} \mathrm{H}\right\}$ NMR $\left(101 \mathrm{MHz}, \mathrm{CD}_{3} \mathrm{CN}\right): \delta 181.6\left(\mathrm{C}_{\mathrm{trz}}-\mathrm{Ru}\right), 159.2(\mathrm{COO}), 154.5\left(\mathrm{C}_{\mathrm{py}} \mathrm{H}\right), 153.7\left(\mathrm{C}_{\mathrm{py}}-\right.$ $\mathrm{N}), 141.9\left(\mathrm{C}_{\mathrm{py}} \mathrm{H}\right), 141.8\left(\mathrm{C}_{\mathrm{trz}}-\mathrm{C}\right), 126.7\left(\mathrm{C}_{\mathrm{py}} \mathrm{H}\right), 125.1,124.8\left(2 \times \mathrm{CH}_{3} \mathrm{CN}\right), 114.7\left(\mathrm{C}_{\mathrm{py}} \mathrm{H}\right), 63.5$ $\left(\mathrm{OCH}_{2}\right), 42.6\left(\mathrm{NCH}_{3}\right), 14.5\left(\mathrm{OCH}_{2} \mathrm{CH}_{3}\right), 4.3,3.9\left(\mathrm{OCH}_{2}, \mathrm{CH}_{3} \mathrm{CN}\right)$. ESI-MS (Cone 20V): 647.2 $[\mathrm{M}-\mathrm{OTf}]^{+}$. The purity of the complex was sufficient for further synthesis (see below). Because of its limited stability, this compound was not further purified.

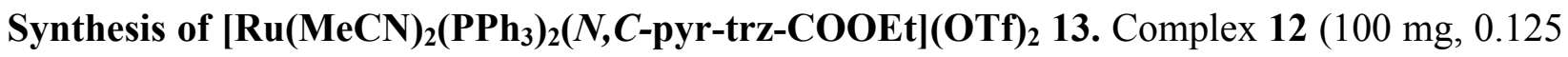
$\mathrm{mmol})$ and $\mathrm{PPh}_{3}(84 \mathrm{mg}, 0.31 \mathrm{mmol})$ were dissolved in $o$-dichlorobenzene $(5 \mathrm{~mL})$, and the suspension was stirred at $110{ }^{\circ} \mathrm{C}$ for 3 days under a nitrogen atmosphere. After cooling, the reaction mixture was poured into $\mathrm{Et}_{2} \mathrm{O}(20 \mathrm{~mL})$ and the formed precipitate was filtered off, washed thoroughly with $\mathrm{Et}_{2} \mathrm{O}$, and dried to yield $\mathbf{1 2}$ as an analytically pure yellow solid (155 $\mathrm{mg}$, 95\%). ${ }^{1} \mathrm{H}$ NMR (400 MHz, $\left.\mathrm{CD}_{3} \mathrm{CN}\right): \delta 8.21\left(\mathrm{~d},{ }^{3} \mathrm{~J}_{\mathrm{HH}}=5.5 \mathrm{~Hz}, 1 \mathrm{H}, \mathrm{H}_{\mathrm{py}}\right), 7.78-7.72\left(\mathrm{~m}, 1 \mathrm{H}, \mathrm{H}_{\mathrm{py}}\right)$, 7.47-7.36 (m, 7H, $\left.\mathrm{H}_{\mathrm{py}}, \mathrm{H}_{\mathrm{PPh} 3}\right), 7.32-7.15\left(\mathrm{~m}, 24 \mathrm{H}, \mathrm{H}_{\mathrm{PPh} 3}\right), 7.09-7.04\left(\mathrm{~m}, 1 \mathrm{H}, \mathrm{H}_{\mathrm{py}}\right), 4.39$ (q, ${ }^{3} \mathrm{~J}_{\mathrm{HH}}=$ $\left.7.1 \mathrm{~Hz}, 1 \mathrm{H}, \mathrm{OCH}_{2}\right), 4.20\left(\mathrm{~s}, 3 \mathrm{H}, \mathrm{NCH}_{3}\right), 2.29\left(\mathrm{~s}, 3 \mathrm{H}, \mathrm{CH}_{3} \mathrm{CN}\right), 1.41\left(\mathrm{t},{ }^{3} \mathrm{~J}_{\mathrm{HH}}=7.1 \mathrm{~Hz}, 3 \mathrm{H}\right.$, $\left.\mathrm{OCH}_{2} \mathrm{CH}_{3}\right) .{ }^{13} \mathrm{C}\left\{{ }^{1} \mathrm{H}\right\}$ NMR $\left(101 \mathrm{MHz}, \mathrm{CD}_{3} \mathrm{CN}\right): \delta 183.4\left(\mathrm{t},{ }^{2} \mathrm{~J}_{\mathrm{CP}}=11.5 \mathrm{~Hz},\left(\mathrm{C}_{\mathrm{trz}}-\mathrm{Ru}\right), 158.2\right.$ (COO), $153.9\left(\mathrm{C}_{\mathrm{py}} \mathrm{H}\right), 150.7\left(\mathrm{C}_{\mathrm{py}}-\mathrm{N}\right), 141.0\left(C_{\mathrm{trz}}-\mathrm{C}\right), 140.6\left(\mathrm{C}_{\mathrm{py}} \mathrm{H}\right), 134.5,134.4\left(2 \times \mathrm{s}, \mathrm{C}_{\mathrm{PPh} 3}\right)$, $133.7\left(\mathrm{t},{ }^{3} \mathrm{~J}_{\mathrm{CP}}=5.5 \mathrm{~Hz}, \mathrm{C}_{\mathrm{PPh} 3}\right), 131.4\left(\mathrm{CH}_{3} \mathrm{CN}\right), 131.1\left(\mathrm{t},{ }^{2} \mathrm{~J}_{\mathrm{CP}}=21.3 \mathrm{~Hz}, \mathrm{C}_{\mathrm{PPh} 3}\right), 127.2\left(\mathrm{C}_{\mathrm{py}} \mathrm{H}\right)$, $114.8\left(\mathrm{C}_{\mathrm{py}} \mathrm{H}\right), 63.8\left(\mathrm{OCH}_{2}\right), 43.9\left(\mathrm{NCH}_{3}\right), 14.4\left(\mathrm{OCH}_{2} \mathrm{CH}_{3}\right), 5.2\left(\mathrm{CH}_{3} \mathrm{CN}\right) \cdot{ }^{31} \mathrm{P}\left\{{ }^{1} \mathrm{H}\right\} \operatorname{NMR}(121$ $\left.\mathrm{MHz}, \mathrm{CD}_{3} \mathrm{CN}\right): \delta 29.5\left(\mathrm{~s}, \mathrm{PPh}_{3}\right)$. Anal. Calcd. for $\mathrm{C}_{53} \mathrm{H}_{48} \mathrm{~F}_{6} \mathrm{~N}_{6} \mathrm{P}_{2} \mathrm{O}_{8} \mathrm{RuS}_{2}\left(1238.12 \mathrm{~g} \mathrm{~mol}^{-1}\right): \mathrm{C}$, 51.81; H, 4.35; N, 6.47. Found: C, 51.90; H, 3.58; N, 5.98. ESI-MS (Cone 20V): 1088.8 [MOTf] $]^{+}$IR $\left(\mathrm{CH}_{3} \mathrm{CN}\right): v=1728 \mathrm{~cm}^{-1}(\mathrm{C}=\mathrm{O})$.

Synthesis of $\left[\mathbf{R u}(\mathbf{M e C N})_{2}\left(\mathbf{P P h}_{3}\right)_{\mathbf{2}}(\mathbf{N}, \boldsymbol{C}\right.$-pyr-trz-COO]OTf 14. Complex 13 (78.5 mg, 0.064 mmol) and $\mathrm{LiOH} \cdot \mathrm{H}_{2} \mathrm{O}(5.4 \mathrm{mg}, 0.13 \mathrm{mmol})$ were mixed in $\mathrm{MeCN}(2 \mathrm{~mL})$ and $\mathrm{H}_{2} \mathrm{O}(1 \mathrm{~mL})$ and the suspension was stirred for $1 \mathrm{~h}$ at $30{ }^{\circ} \mathrm{C}$. The reaction mixture was extracted with $\mathrm{CH}_{2} \mathrm{Cl}_{2} / \mathrm{H}_{2} \mathrm{O}$ mixtures. The organic layers were combined and the solvent was removed under reduced 
pressure. The residue was dissolved in $\mathrm{MeCN}$ and precipitated with $\mathrm{Et}_{2} \mathrm{O}$ to afforded $\mathbf{1 4}$ as a yellow solid. Yield: $46 \mathrm{mg}, 64 \% .{ }^{1} \mathrm{H}$ NMR $\left(500 \mathrm{MHz}, \mathrm{CD}_{3} \mathrm{CN}\right): \delta 7.99\left(\mathrm{~d},{ }^{3} \mathrm{~J}_{\mathrm{HH}}=5.2 \mathrm{~Hz}, 1 \mathrm{H}\right.$, $\left.\mathrm{H}_{\mathrm{py}}\right), 7.72-7.67\left(\mathrm{~m}, 1 \mathrm{H}, \mathrm{H}_{\mathrm{py}}\right), 7.45-7.22\left(\mathrm{~m}, 30 \mathrm{H}, \mathrm{H}_{\mathrm{Pph} 3}\right), 7.18-7.15\left(\mathrm{~m}, 1 \mathrm{H}, \mathrm{H}_{\mathrm{py}}\right), 7.07-7.03(\mathrm{~m}$, $\left.1 \mathrm{H}, \mathrm{H}_{\mathrm{py}}\right), 4.21\left(\mathrm{~s}, 3 \mathrm{H}, \mathrm{NCH}_{3}\right), 2.16\left(\mathrm{~s}, 3 \mathrm{H}, \mathrm{CH}_{3} \mathrm{CN}\right) \cdot{ }^{13} \mathrm{C}\left\{{ }^{1} \mathrm{H}\right\} \mathrm{NMR}\left(126 \mathrm{MHz}, \mathrm{CD}_{3} \mathrm{CN}\right): \delta 173.9$ (m, $\left.\mathrm{C}_{\mathrm{trz}}-\mathrm{Ru}\right), 161.3(\mathrm{COO}), 153.0\left(\mathrm{C}_{\mathrm{py}} \mathrm{H}\right), 152.0\left(\mathrm{C}_{\mathrm{py}}-\mathrm{N}\right), 150.0\left(C_{\mathrm{trz}}-\mathrm{C}\right), 139.9\left(\mathrm{C}_{\mathrm{py}} \mathrm{H}\right), 134.7$, $134.5\left(2 \times \mathrm{s}, \mathrm{C}_{\mathrm{PPh} 3}\right), 134.2\left(\mathrm{t},{ }^{3} \mathrm{~J}_{\mathrm{CP}}=5.5 \mathrm{~Hz}, \mathrm{C}_{\mathrm{PPh} 3}\right), 131.0\left(\mathrm{t},{ }^{2} \mathrm{~J}_{\mathrm{CP}}=20.9 \mathrm{~Hz}, \mathrm{C}_{\mathrm{PPh} 3}\right), 130.9$ $\left(\mathrm{CH}_{3} \mathrm{CN}\right), 126.3\left(\mathrm{C}_{\mathrm{py}} \mathrm{H}\right), 114.5\left(\mathrm{C}_{\mathrm{py}} \mathrm{H}\right), 41.2\left(\mathrm{NCH}_{3}\right), 5.3\left(\mathrm{CH}_{3} \mathrm{CN}\right) \cdot{ }^{31} \mathrm{P}\left\{{ }^{1} \mathrm{H}\right\} \mathrm{NMR}(121 \mathrm{MHz}$, $\left.\mathrm{CD}_{3} \mathrm{CN}\right): \delta 32.0\left(\mathrm{~s}, \mathrm{PPh}_{3}\right)$. Anal. Calcd. for $\mathrm{C}_{50} \mathrm{H}_{43} \mathrm{~F}_{3} \mathrm{~N}_{6} \mathrm{P}_{2} \mathrm{O}_{5} \mathrm{RuS} \cdot \times 4 \mathrm{H}_{2} \mathrm{O}\left(1132.05 \mathrm{~g} \mathrm{~mol}^{-1}\right): \mathrm{C}$, 53.05; H, 4.54; N, 7.42. Found: C, 53.03; H, 4.76; N, 6.93. ESI-MS (Cone 20V): 869.9 [M-OTf$\mathrm{MeCN}]^{+}$. IR $\left(\mathrm{CH}_{3} \mathrm{CN}\right) v=1645.2 \mathrm{~cm}^{-1}(\mathrm{C}=\mathrm{O})$.

Synthesis of $\left[\mathbf{R u}(\mathbf{M e C N})_{2}\left(\mathbf{P P h}_{\mathbf{3}}\right)_{\mathbf{2}}(\boldsymbol{N}, \boldsymbol{C} \text {-pyr-trz-COOH](OTf })_{2} \mathbf{1 5}_{\text {15. Complex }} 13\right.$ (78.5 mg, 0.064 $\mathrm{mmol})$ and $\mathrm{LiOH} \cdot \mathrm{H}_{2} \mathrm{O}(5.4 \mathrm{mg}, 0.13 \mathrm{mmol})$ were mixed in $\mathrm{MeCN}(2 \mathrm{~mL})$ and $\mathrm{H}_{2} \mathrm{O}(1 \mathrm{~mL})$ and the suspension was stirred for $1 \mathrm{~h}$ at $30{ }^{\circ} \mathrm{C}$. The reaction mixture was acidified with aqueous triflic acid $(1 \mathrm{M})$ and extracted with $\mathrm{CH}_{2} \mathrm{Cl}_{2} / \mathrm{H}_{2} \mathrm{O}$ mixtures. The organic layers were combined and the solvent was removed under reduced pressure. The residue was dissolved in $\mathrm{MeCN}$ an precipitated with $\mathrm{Et}_{2} \mathrm{O}$ to give complex 15 as a yellow, highly hygroscopic solid (40 mg, 52\%). Because of the hygroscopic nature of the complex, we have not succeeded in obtaining satisfactory microanalytical results. ${ }^{1} \mathrm{H}$ NMR $\left(400 \mathrm{MHz}, \mathrm{CD}_{3} \mathrm{CN}\right): \delta 8.03\left(\mathrm{~d},{ }^{3} \mathrm{~J}_{\mathrm{HH}}=5.6 \mathrm{~Hz}, 1 \mathrm{H}\right.$, $\left.\mathrm{H}_{\mathrm{py}}\right), 7.75-7.67\left(\mathrm{~m}, 1 \mathrm{H}, \mathrm{H}_{\mathrm{py}}\right), 7.45-7.21\left(\mathrm{~m}, 31 \mathrm{H}, \mathrm{H}_{\mathrm{PPh} 3}, \mathrm{H}_{\mathrm{py}}\right), 7.08-7.00\left(\mathrm{~m}, 1 \mathrm{H}, \mathrm{H}_{\mathrm{py}}\right), 4.24(\mathrm{~s}$, $\left.3 \mathrm{H}, \mathrm{NCH}_{3}\right)$, coordinated MeCN not detected. ${ }^{13} \mathrm{C}\left\{{ }^{1} \mathrm{H}\right\}$ NMR $\left(101 \mathrm{MHz}, \mathrm{CD}_{3} \mathrm{CN}\right): \delta 173.5\left(\mathrm{C}_{\mathrm{trz}}-\right.$ $\mathrm{Ru}), 160.4(\mathrm{COO}), 152.2\left(\mathrm{C}_{\mathrm{py}} \mathrm{H}\right), 151.0\left(\mathrm{C}_{\mathrm{py}}-\mathrm{N}\right), 148.4\left(C_{\mathrm{trz}}-\mathrm{C}\right), 139.1\left(\mathrm{C}_{\mathrm{py}} \mathrm{H}\right), 133.7,133.6(2 \times$ $\left.\mathrm{s}, \mathrm{C}_{\mathrm{PPh} 3}\right), 133.2\left(\mathrm{t},{ }^{3} \mathrm{~J}_{\mathrm{CP}}=5.5 \mathrm{~Hz}, \mathrm{C}_{\mathrm{PPh} 3}\right), 130.1\left(\mathrm{t},{ }^{2} \mathrm{~J}_{\mathrm{CP}}=20.9 \mathrm{~Hz}, \mathrm{C}_{\mathrm{PPh} 3}\right), 130.0\left(\mathrm{CH}_{3} \mathrm{CN}\right), 125.4$ $\left(\mathrm{C}_{\mathrm{py}} \mathrm{H}\right), 113.6\left(\mathrm{C}_{\mathrm{py}} \mathrm{H}\right), 40.4\left(\mathrm{NCH}_{3}\right), 4.4\left(\mathrm{CH}_{3} \mathrm{CN}\right) .{ }^{31} \mathrm{P}\left\{{ }^{1} \mathrm{H}\right\} \mathrm{NMR}\left(162 \mathrm{MHz}, \mathrm{CD}_{3} \mathrm{CN}\right): \delta 36.7(\mathrm{~s}$, $\mathrm{PPh}_{3}$ ). ESI-MS (Cone 20V): $415.6[\mathrm{M}-\mathrm{OTf}-2(\mathrm{MeCN})]^{2+}$.

General procedure for transfer hydrogenation. In a one-neck round bottom flask, a mixture of acetophenone $(0.6 \mathrm{mmol})$, ruthenium complex $(6 \mu \mathrm{mol})$, a solution of $\mathrm{KOH}(2 \mathrm{M}, 0.06 \mathrm{mmol})$ and anisole $(0.6 \mathrm{mmol})$ as internal standard in 2-propanol $(2 \mathrm{~mL})$ was heated to reflux for the time indicated. The reaction mixture was analyzed by ${ }^{1} \mathrm{H}$ NMR spectroscopy by diluting aliquots $(0.1 \mathrm{~mL})$ of the reacting mixture with $\mathrm{CDCl}_{3}(0.5 \mathrm{~mL})$. Conversions and yields were determined relative to anisole.

General procedure for base-free dehydrogenation of alcohols. In a one-neck round bottom flask, a mixture of benzyl alcohol $(0.2 \mathrm{mmol})$, ruthenium complex $(0.01 \mathrm{~mol})$, and anisole $(0.2$ $\mathrm{mmol})$ as internal standard was heated in 1,2-dichlorobenzene $(2 \mathrm{~mL})$ at $150{ }^{\circ} \mathrm{C}$ for $16 \mathrm{~h}$. 
Aliquots $(0.1 \mathrm{~mL})$ of the reacting solution were dissolved in $\mathrm{CDCl}_{3}(0.5 \mathrm{~mL})$ and analyzed by ${ }^{1} \mathrm{H}$ NMR spectroscopy. Conversions and yields were determined relative to anisole.

For deuterium labeling studies, $\left(\mathrm{CD}_{3}\right)_{2} \mathrm{CD}-\mathrm{OH}$ was prepared by stirring a mixture of commercially available $\left(\mathrm{CD}_{3}\right)_{2} \mathrm{CD}-\mathrm{OD}$ in $\mathrm{H}_{2} \mathrm{O}(1: 5 \mathrm{v} / \mathrm{v})$ for $2 \mathrm{~h}$ at room temperature. The mixture was extracted with $\mathrm{CH}_{2} \mathrm{Cl}_{2}$ and the combined organic fractions were distilled.

Crystal-Structure Determination. Crystal data for complex $\mathbf{6}$ and $\mathbf{9}$ were collected on a Rigaku Oxford Diffraction (former Agilent Technologies, former Oxford Diffraction) SuperNova A diffractometer using mirror optics monochromated $\mathrm{Cu}(\lambda=1.54184 \AA$, 6) and $\mathrm{Mo}(\lambda=0.71073$ $\AA$, 9) $K \alpha$ radiation, respectively. A fourfold redundant dataset for 6 was collected at $100 \mathrm{~K}$, assuming the Friedel pairs are not equivalent. The data for $\mathbf{9}$, fivefold redundant based on nonequivalent Friedel pairs, had to be collected at room temperature as the crystals of $\mathbf{9}$ underwent a gradual phase transition into a modulated structure upon cooling. The satellite peaks became visible from about 240K. Data reduction was performed using the CrysAlisPro program. The intensities were corrected for Lorentz and polarization effects, and an absorption correction based on the multiscan method using SCALE3 ABSPACK in CrysAlisPro was applied. ${ }^{78}$ All structures were solved by direct methods using SHELXS-97 and refined by full-matrix least squares fitting on $\mathrm{F}^{2}$ for all data using SHELXL-9 $7^{79}$. Hydrogen atoms were added at calculated positions and refined by using a riding model. Anisotropic thermal displacement parameters were used for all nonhydrogen atoms. Further crystallographic details are compiled in Tables S1 and S2. Crystallographic data (excluding structure factors) for both complexes have been deposited with the Cambridge Crystallographic Data Centre as supplementary publication no. 1475358 (6) and 1475357 (9).

Acknowledgements: We gratefully acknowledge financial support from the European Research Council (CoG 615653), the Swiss National Science Foundation (200021_162868), and the 'Generalitat Valenciana' for a fellowship (S. Sabater). We thank E. Peris and J. Mata (Univ Jaume I) for fruitful discussion.

Supporting Information: X-ray diffraction data. This material is Representative timeconversion profile for catalytic activity of complex 3a, and Crystallographic data for complexes 6 and 9 in cif format. This material is available free of charge via the Internet at http://pubs.acs.org.

Notes: The authors declare no competing financial interests. 


\section{References}

(1) Hartwig, J. Organotransition metal chemistry: from bonding to catalysis; Mill Valley CA, 2010 .

(2) Tolman, C. A. Chem. Rev. 1977, 77, 313-348.

(3) Kaim, W. Eur. J. Inorg. Chem. 2012, 343-348.

(4) Chirik, P. J. Inorg. Chem. 2011, 50, 9737-9740.

(5) Hindson, K.; de Bruin, B. Eur. J. Inorg. Chem. 2012, 340-342.

(6) Ikariya, T.; Murata, K.; Noyori, R. Org. Biomol. Chem. 2006, 4, 393-406.

(7) Grützmacher, H. Angew. Chem. Int. Ed. 2008, 47, 1814-1818.

(8) Askevold, B.; Roesky, H. W.; Schneider, S. ChemCatChem 2012, 4, 307-320.

(9) Noyori, R.; Yamakawa, M.; Hashiguchi, S. J. Org. Chem. 2001, 66, 7931-7944.

(10) Mathew, P.; Neels, A.; Albrecht, M. J. Am. Chem. Soc. 2008, 130, 13534-13535.

(11) Donnelly, K. F.; Petronilho, A.; Albrecht, M. Chem. Commun. 2013, 49, 1145-1159.

(12) Crowley, J. D.; Lee, A.; Kilpin, K. J. Aust. J. Chem. 2011, 64, 1118-1132.

(13) Guisado-Barrios, G.; Bouffard, J.; Donnadieu, B.; Bertrand, G. Angew. Chem. Int. Ed. 2010, 49, 4759-4762.

(14) Crabtree, R. H. Coord. Chem. Rev. 2013, 257, 755-766.

(15) Albrecht, M. Adv. Organomet. Chem. 2014, 62, 111-158.

(16) Schuster, O.; Yang, L.; Raubenheimer, H. G.; Albrecht, M. Chem. Rev. 2009, 109, 34453478.

(17) Krüger, A.; Albrecht, M. Aust. J. Chem. 2011, 64, 1113.

(18) For other approaches, see e.g.: Bouffard, J.; Keitz, B. K.; Tonner, R.; Lavallo, V.; Guisado-Barrios, G.; Frenking, G.; Grubbs, R. H.; Bertrand, G. Organometallics 2011, 30, 2617-2627.

(19) Meldal, M.; Tomoe, C. W. Chem. Rev. 2008, 108, 2952-3015.

(20) Bock, V. D.; Hiemstra, H.; Van Maarseveen, J. H. Eur. J. Org. Chem. 2006, 51-68.

(21) Worrell, B. T.; Malik, J. A.; Fokin, V. V. Science 2013, 340, 457-460.

(22) Kolb, H. C.; Finn, M. G.; Sharpless, K. B. Angew. Chem. Int. Ed. 2001, 40, 2004-2021.

(23) McGuinness, D. S.; Cavell, K. J. Organometallics 2000, 19, 741-748.

(24) Normand, A. T.; Cavell, K. J. Eur. J. Inorg. Chem. 2008, 2781-2800.

(25) Dobereiner, G. E.; Chamberlin, C. A.; Schley, N. D.; Crabtree, R. H. Organometallics 2010, 29, 5728-5731.

(26) Poyatos, M.; Mata, J. A.; Peris, E. Chem. Rev. 2009, 109, 3677-3707. 
(27) Peris, E.; Crabtree, R. H. Coord. Chem. Rev. 2004, 248, 2239-2246.

(28) Chen, J. C. C.; Lin, I. J. B. Synthesis 2000, 19, 5113-5121.

(29) Specht, Z. G.; Cortes-Llamas, S. A.; Tran, H. N.; Van Niekerk, C. J.; Rancudo, K. T.; Golen, J. A.; Moore, C. E.; Rheingold, A. L.; Dwyer, T. J.; Grotjahn, D. B. Chem. Eur. J. 2011, 17, 6606-6609.

(30) Specht, Z. G.; Grotjahn, D. B.; Moore, C. E.; Rheingold, A. L. Organometallics 2013, 32, 6400-6409.

(31) Leung, C. H.; Incarvito, C. D.; Crabtree, R. H. Organometallics 2006, 25, 6099-6107.

(32) Yamamoto, H. Lewis Acids in Organic Synthesis; Wiley-VHC: New York, 2000.

(33) Huynh, M. H. V; Meyer, T. J. Chem. Rev. 2007, 107, 5004-5064.

(34) Grotjahn, D. B. Chem. Eur. J. 2005, 11, 7146-7153.

(35) Mas-Marzá, E.; Peris, E.; Castro-Rodríguez, I.; Meyer, K. Organometallics 2005, 24, 3158-3162.

(36) Power, P. P. Nature 2010, 463, 171-177.

(37) Stephan, D. W.; Erker, G. Angew. Chem. Int. Ed. 2010, 49, 46-76.

(38) Hounjet, L. J.; Stephan, D. W. Org. Process Res. Dev. 2014, 18, 385-391.

(39) Eisenberger, P.; Bestvater, B. P.; Keske, E. C.; Crudden, C. M. Angew. Chem. Int. Ed. 2015, 54, 2467-2471.

(40) Paradies, J. Angew. Chem. Int. Ed. 2014, 53, 3552-3557.

(41) Flynn, S. R.; Wass, D. F. ACS Catal. 2013, 3, 2574-2581.

(42) Chattopadhyay, B.; Vera, C. I. R.; Chuprakov, S.; Gevorgyan, V. Org. Lett. 2010, 12, 2166-2169.

(43) Bolje, A.; Košmrlj, J. Org. Lett. 2013, 15, 5084-5087.

(44) Bolje, A.; Urankar, D.; Košmrlj, J. Eur. J. Org. Chem. 2014, 8167-8181.

(45) Woods, J. A.; Lalrempuia, R.; Petronilho, A.; McDaniel, N. D.; Müller-Bunz, H.; Albrecht, M.; Bernhard, S. Energy Environ. Sci. 2014, 7, 2316.

(46) Voutchkova, A. M.; Appelhans, L. N.; Chianese, A. R.; Crabtree, R. H. J. Am. Chem. Soc. 2005, 127, 17624-17625.

(47) Roselló-Merino, M.; Díez, J.; Conejero, S. Chem. Commun. 2010, 46, 9247-9249.

(48) Prades, A.; Peris, E.; Albrecht, M. Organometallics 2011, 30, 1162-1167.

(49) Canseco-Gonzalez, D.; Albrecht, M. Dalton Trans. 2013, 42, 7424-7432.

(50) Delgado-Rebollo, M.; Canseco-Gonzalez, D.; Hollering, M.; Mueller-Bunz, H.; Albrecht, M. Dalton Trans. 2014, 43, 4462-4473.

(51) Bernet, L.; Lalrempuia, R.; Ghattas, W.; Mueller-Bunz, H.; Vigara, L.; Llobet, A.; Albrecht, M. Chem. Commun. 2011, 47, 8058.

(52) Bagh, B.; McKinty, A. M.; Lough, A. J.; Stephan, D. W. Dalton Trans. 2014, 43, $12842-$ 
12850.

(53) Ogata, K.; Inomata, S.; Fukuzawa, S. Dalton Trans. 2013, 42, 2362-2365.

(54) Donnelly, K. F.; Lalrempuia, R.; Mu, H.; Albrecht, M. Organometallics 2012, $31,8414$.

(55) Bolje, A.; Hohloch, S.; Urankar, D.; Pevec, A.; Gazvoda, M.; Sarkar, B.; Košmrlj, J. Organometallics 2014, 33, 2588-2598.

(56) Petronilho, A.; Woods, J. A.; Bunz, H. M.; Bernhard, S.; Albrecht, M. Chem. Eur. J. 2014, $20,15775-15784$.

(57) Su, H. L.; Perez, L. M.; Lee, S. J.; Reibenspies, J. H.; Bazzi, H. S.; Bergbreiter, D. E. Organometallics 2012, 31, 4063-4071.

(58) Caytan, E.; Roland, S. Organometallics 2014, 33, 2115-2118.

(59) Oomens, J.; Steill, J. D. J. Phys. Chem. A 2008, 112, 3281-3283.

(60) Ghattas, W.; Mueller-Bunz, H.; Albrecht, M. Organometallics 2010, 29, 6782-6789.

(61) Leigh, V.; Ghattas, W.; Lalrempuia, R.; Müller-Bunz, H.; Pryce, M. T.; Albrecht, M. Inorg. Chem. 2013, 52, 5395-5402.

(62) Nussbaum, M.; Schuster, O.; Albrecht, M. Chem. Eur. J. 2013, 19, 17517-17527.

(63) Le Lagadec, R.; Rubio, L.; Alexandrova, L.; Toscano, R. A.; Ivanova, E. V.; Meškys, R.; Laurinavičius, V.; Pfeffer, M.; Ryabov, A. D. J. Organomet. Chem. 2004, 689, 48204832.

(64) Burling, S.; Mahon, M. F.; Powell, R. E.; Whittlesey, M. K.; Williams, J. M. J. J. Am. Chem. Soc. 2006, 128, 13702-13703.

(65) Clapham, S. E.; Hadzovic, A.; Morris, R. H. Coord. Chem. Rev. 2004, 248, 2201-2237.

(66) Gunanathan, C.; Milstein, D. Acc. Chem. Res. 2011, 44, 588-602.

(67) Burling, S.; Paine, B. M.; Nama, D.; Brown, V. S.; Mahon, M. F.; Prior, T. J.; Pregosin, P. S.; Whittlesey, M. K.; Williams, J. M. J. J. Am. Chem. Soc. 2007, 129, 1987-1995.

(68) Chelucci, G.; Baldino, S.; Baratta, W. Acc. Chem. Res. 2015, 48, 363-379.

(69) Shvo, Y.; Czarkie, D.; Rahamim, Y.; Chodosh, D. F. J. Am. Chem. Soc. 1986, 108, 74007402 .

(70) Johnson, T. C.; Morris, D. J.; Wills, M. Chem. Soc. Rev. 2010, 39, 81-88.

(71) Conley, B. L.; Pennington-Boggio, M. K.; Boz, E.; Williams, T. J. Chem. Rev. 2010, 110, 2294-2312.

(72) Noyori, R.; Ohkuma, T. Angew. Chem. Int. Ed. 2001, 40, 40-73.

(73) Zassinovich, G.; Mestroni, G.; Gladiali, S. Chem. Rev. 1992, 92, 1051-1069.

(74) Samec, J. S. M.; Bäckvall, J.-E.; Andersson, P. G.; Brandt, P. Chem. Soc. Rev. 2006, 35, 237-248.

(75) Chelucci, G.; Baldino, S.; Baratta, W. Coord. Chem. Rev. 2015, 300, $29-85$.

(76) Wang, D.; Astruc, D. Chem. Rev. 2015, 115, 6621-6686. 
(77) Klomp, D.; Hanefeld, U.; Peters, J. A. In The Handbook of Homogeneous Hydrogenation; de Vries, J. G., Elsevier, C. J., Eds.; Wiley-VHC: Weinheim, Germany, 2007; pp 585-630.

(78) Ruff, A.; Kirby, C.; Chan, B. C.; O'Connor, A. R. Organometallics 2016, 35, 327-335.

(79) Corberán, R.; Peris, E. Organometallics 2008, 27, 1954-1958.

(80) Bolje, A.; Hohloch, S.; van der Meer, M.; Košmrlj, J.; Sarkar, B. Chem. Eur. J. 2015, 21, 6756-6764.

(81) Mestroni, G.; Zassinovich, G.; Camus, A.; Martinelli, F. J. Organomet. Chem. 1980, 198, 87-96.

(82) Yang, H.; Alvarez, M.; Lugan, N.; Mathieu, R. J. Chem. Soc. Chem. Commun. 1995, 1721.

(83) Dani, P.; Karlen, T.; Gossage, R.; Gladiali, S.; van Koten G. Angew. Chem. Int. Ed.. 2000, $39,743-745$.

(84) Albrecht, M.; Miecznikowski, J. R.; Samuel, A.; Faller, J. W.; Crabtree, R. H. Organometallics 2002, 21, 3596-3604.

(85) Thoumazet, C.; Melaimi, M.; Ricard, L.; Mathey, F.; Le Floch, P. Organometallics 2003, $22,1580-1581$.

(86) Baratta, W.; Chelucci, G.; Gladiali, S.; Siega, K.; Toniutti, M.; Zanette, M.; Zangrando, E.; Rigo, P. Angew. Chem. Int. Ed. 2005, 44, 6214-6219.

(87) Zuo, W.; Lough, A. J.; Li, Y. F.; Morris, R. H. Science 2013, 342, 1080-1083.

(88) The difference in activity compared to the data in Table 1, entries 4,6 are attributed to the repetitive sampling, which induced a gradual loss of activity over longer reaction times.

(89) Attempts to isolate a complex from the reaction mixture after catalysis have failed thus far.

(90) Pàmies, O.; Bäckvall, J. E. Chem. Eur. J. 2001, 7, 5052-5058.

(91) Widegren, J. A.; Finke, R. G. J. Mol. Catal. A. 2003, 198, 317-341.

(92) Hohloch, S.; Hettmanczyk, L.; Sarkar, B. Eur. J. Inorg. Chem. 2014, 3164-3171.

(93) Clark, R. C.; Reid, J. S. Acta Crystallogr. Sect. A. 1995, 51, 887-897.

(94) Sheldrick, G. M. Acta Crystallogr. Sect. A. 2007, 64, 112-122. 
Entry for tables of content

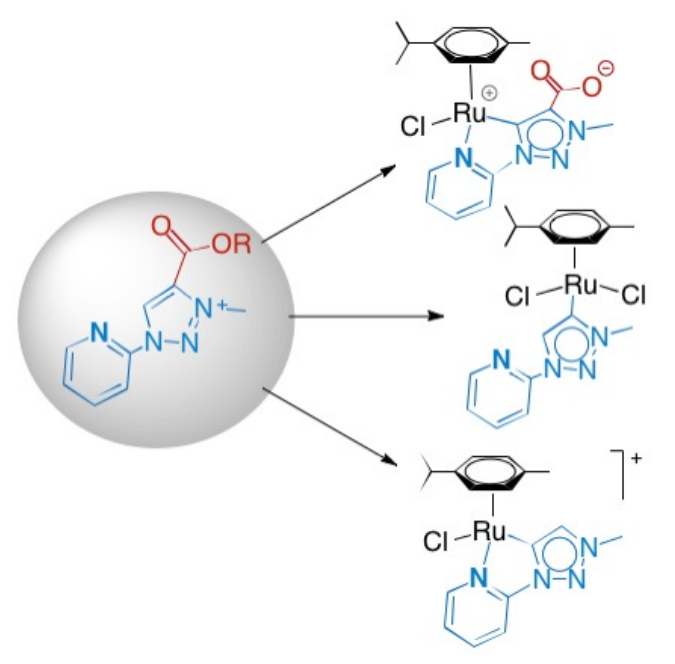

